\title{
Mikrosejsmika, sejsmika, sejsmologia - wspólne korzenie, różne cele, zintegrowane działania
}

\begin{abstract}
W publikacji scharakteryzowano krótko ważniejsze informacje z wybranych dziedzin nauk o Ziemi, które doprowadziły do sformułowania zasad monitorowania mikrosejsmicznego, jako narzędzia śledzenia i oceny skuteczności szczelinowania hydraulicznego. Rozpoznanie przedstawionych w bogatej literaturze światowej rozwiązań opartych na studium rzeczywistych przypadków realizowanych przez kampanie przemysłu poszukiwań ropy i gazu w różnych i różnorodnie położonych miejscach globu doprowadziło do konkluzji, że przypuszczalne i udokumentowane do chwili obecnej formacje łupkowe w Polsce, z usprawiedliwiającym udostępnianie i produkcję potencjałem węglowodorowym, wymagają rozwiązań przygotowujących i konkretnych działań przemysłowych, różnych od najczęściej stosowanych na świecie, co związane jest przede wszystkim ze specyfiką ich budowy geologicznej. Za ważny czynnik na drodze do sukcesu poszukiwawczego uznano rozpoznanie a priori wielorakich opcji reakcji ośrodka geologicznego (geological response) na działalność inżynieryjną. W konsekwencji zaproponowano i przedstawiono koncepcję i algorytm trójwymiarowego modelowania mikrosejsmicznego, umożliwiającego symulację odpowiedzi sprężystej ośrodka na wzbudzanie i zaburzenie równowagi naprężeń spowodowane szczelinowaniem hydraulicznym.
\end{abstract}

Komentowane badanie przeprowadzono w ramach realizacji programu BLUE GAS - projekt GASŁUPMIKROS.

Słowa kluczowe: sejsmologia, metoda sejsmiczna, fale mikrosejsmiczne, model mechaniczny, tensor naprężeń, parametry wytrzymałości skał, modelowanie pola sprężystego, szczelinowanie hydrauliczne.

\section{Microseismics, seismics, seismology - common roots, different aims, integrated activities}

In the paper, selected elements and concepts of the most important disciplines of Earth Sciences, which led to the formulation of rules of seismic monitoring, as a tool to track and evaluate the effectiveness of hydraulic fracturing. Recognition of solutions presented in a wide scope of literature and works, based on actual cases carried out by the oil and gas industry during hydrocarbons exploration in different object across the globe, led to the conclusion that the potential and documented until now in Polish shale formation, require specific solutions and actions to be taken by the industry, different from those most commonly used in the world. An important aspect on the way to successful exploration was to recognize a priori the geological response of reservoir formation to the engineering activities. As a result, the concept of three-dimensional microseismic modeling enabling simulation of elastic response of rock medium to inducing and loss of stresses equilibrium due to hydraulic fracturing was proposed and presented. Results of calculations performed in MICROMOD 3D software, implemented for geological models created based on data measured in L-1 borehole were discussed.

Likely directions of further development of the software, especially regarding the visualization of graphic results were also presented.

Key words: seismology, seismics methods, microseismics waves, geomechanical model, stress tensor, strength properties of rocks, elastic field modeling, hydraulic fracturing.

\section{Wprowadzenie}

W każdej dziedzinie aktywności człowieka - w gospodarce, nauce, kulturze - pojawianie się nowych zadań, zarówno łatwiejszych, jak i tych bardzo trudnych, które dziś najczęściej nazywane są wyzwaniami, powinno skutkować dla człowieka 
pozytywnie - wszechstronnym rozwojem: rozwojem myśli, technologii, poziomu środowiska, egzystencji. W takiej też perspektywie rozwoju oceniana jest słuszność podejmowania określonych wyzwań, a co za tym idzie - angażowania nakładów finansowych i czasowych na rozwiązywanie nowych ważnych zadań przez środowiska gospodarcze i państwa.

Wyzwaniem, które w Polsce w okresie minionych kilku lat wywołało duże poruszenie i dyskusję, zarówno merytoryczną w środowiskach profesjonalnych, jak i ogólnomedialną w różnych ośrodkach przekazu informacji, stał się tzw. boom łupkowy, czyli informacja o wysokim prawdopodobieństwie występowania bogatych złóż gazu w formacjach łupków paleozoicznych. Obecnie problematyka złóż niekonwencjonalnych i polskiego ,gazu z łupków” posiada bardzo bogatą bibliografię, zarówno rodzimą [13, 15-29], jak i przede wszystkim światową [1-12, 14, 30-39]. Przed środowiskiem geonaukowców stanęło nie tylko zagadnienie lokalizacji tych specyficznych złóż, nazywanych niekonwencjonalnymi, ale też opracowania lub zaadaptowania znanych na świecie sposobów i metod ich eksploatacji, jak również - co bardzo ważne - oceny ryzyka ekonomicznego oraz technologicznego wynikającego z ich udostępnienia i doprowadzenia do produkcji.

Bez względu na przyszłe, nieznane jeszcze obecnie w odniesieniu do sytuacji w Polsce efekty ekonomiczne stwierdzić można, że wspomniany boom łupkowy skutkuje już dzisiaj dedykowanym sobie rozwojem myśli i technologii w dziedzinie nauk o Ziemi - geologii, geofizyce, inżynierii złożowej. Wyraźnie też manifestuje się konieczność silnej integracji tych gałęzi wiedzy.

W dalszych rozdziałach artykułu przedstawiono algorytm i program do trójwymiarowego modelowania zdarzeń mikrosejsmicznych, który jest autorskim rozwiązaniem realizatorów zadania (Przetwarzanie i interpretacja danych mikrosejsmicznych oraz symulacje numeryczne fal generowanych $w$ procesie szczelinowania hydraulicznego, $w$ tym mikrosejsmika - aktywna i pasywna - w celu określenia dynamicznych zmian w ośrodku wywołanych procesami udostepniania i eksploatacji formacji tupkowych) z ramienia INiG - PIB (Halina Jędrzejowska-Tyczkowska, Krystyna Żukowska, Irena Irlik).

Trudno porównywać istotę merytoryczną opracowanego rozwiązania $\mathrm{z}$ istniejącymi i funkcjonującymi zapewne propozycjami komercyjnymi, które - jeżeli są zakupywane - to zawsze na zasadzie „czarnej skrzynki”, bowiem koncepcje $\mathrm{i}$ istotne rozwiązania metodyczne są przedmiotem patentów.

Najbogatszą znaną autorowi informację na temat mikrosejsmiki stanowią materiały kursu przedstawione przez grupę „SEJSMIK” Leo Eisnera pt. Microseismic monitoring in oil or gas reservoirs [9].

\section{W poszukiwaniu korzeni}

W obliczu potrzeb, które przynoszą poszukiwanie, udostępnianie oraz eksploatacja złóż gazu z formacji lupkowych, wspomniana wyżej integracja musi się dokonywać na kilku różnych poziomach, poczynając od podstawowych założeń teoretycznych, poprzez sposoby akwizycji i zapisu procesu propagacji drgań oraz metodykę przetwarzania, kończąc na koncepcjach i idei rozumienia oraz interpretacji geologicznej i geofizycznej wyników.

W przemyśle poszukiwań nafty i gazu zarówno na świecie, jak i w Polsce najszersze zastosowanie zdobyła metoda sejsmiczna. I chociaż korzenie metody tkwią w sejsmologii, badaniu mechanizmu źródła trzęsień ziemi, o skutkach niekiedy katastrofalnych, właściwie przez całe lata wykorzystywania metody sejsmicznej niewiele działań znanych w sejsmologii zostało wprost przeniesionych do sejsmiki. Wydaje się, że nie było takiej potrzeby. Wręcz odwrotnie - w pewnym momencie, w latach 90 . minionego stulecia, wiele sposobów przetwarzania znanych w sejsmice zostało zaadaptowanych w sejsmologii; dotyczy to szczególnie problematyki analizy sygnału.

Drgania mikrosejsmiczne, ciągły proces rozprzestrzeniania się w skorupie ziemskiej fal sprężystych o słabej i bardzo słabej energii - mające swoje przyczyny w procesach naturalnych, nawet oddziaływaniu księżyca, ale też w cywilizacyjnych, jak przemysł, transport, kopalnictwo i prace górnicze - w przemyśle naftowym nie były brane pod uwagę jako źródło informacji, nie stanowiąc konkurencji dla metody sejsmicznej, o a priori programowanej sile wzbudzenia, a w konsekwencji o przewidywalnej wielkości wyemitowanej energii i wywołanych odkształceń. Dopiero pojawienie się konieczności monitorowania przebiegu i efektów szczelinowania hydraulicznego wskazało na możliwości wykorzystania drgań mikrosejsmicznych jako nośnika informacji o stanie ośrodka geologicznego. Sposób przyjął nazwę mikrosejsmiki i uświadamia istnienie podstawowej, najgłębszej platformy integracji metod wykorzystujących drgania sprężyste w przemyśle poszukiwań naftowych, a mianowicie właściwości mechanicznych ośrodka geologicznego.

Jest intuicyjnie oczywiste, że proces propagacji drgań sprężystych oraz jego skutki, szczególnie w ośrodku stałym (ale i ciekłym), zależą przede wszystkim od właściwości mechanicznych ośrodka, takich jak gęstość, twardość, zwięzłość, stan naprężeń i ciśnienie porowe. Niektóre z wymienionych właściwości mogą być mierzone wprost w laboratoriach, 
inne są uzyskiwane wyłącznie pośrednio - obliczane na podstawie równań i relacji z „mierzalnymi” parametrami. Do takich „niemierzalnych” parametrów ośrodka geologicznego należy stan naprężeń; jak to obrazowo zauważyli J. Herwanger i N. Koutsabeloulis w materiałach edukacyjnych EAGE pt. Seismic Geomechanics - nie dysponujemy instrumentem typu ,stress meter".

Widząc niekwestionowaną rolę znajomości modelu mechanicznego w analizie i interpretacji danych sejsmicznych, należy zwrócić uwagę na istnienie relacji odwrotnej, która umożliwia obliczenie parametrów wytrzymałościowych ośrodka, czyli wspomnianego stanu naprężeń, na podstawie znajomości pewnych ,mierzalnych” parametrów sprężystych, a przede wszystkim prędkości propagacji fal podłużnych $V p[\mathrm{~m} / \mathrm{s}]$ i poprzecznych $V s[\mathrm{~m} / \mathrm{s}]$. Stan naprężeń ośrodka geologicznego zależy od trzech podstawowych czynników:

- budowy strukturalnej (topografii powierzchni, geometrii uwarstwienia, lokalizacji i orientacji uskoków);

- rozkładu właściwości fizycznych ośrodka stałego;

- naprężeń zewnętrznych (naprężeń tektonicznych i ciśnień porowych).

Uwzględniając możliwość kalibracji parametrów „obliczanych” za pomocą parametrów „mierzonych” oraz możliwość wykorzystania wyników sejsmiki 4D (time lapse) do prognozowania dynamiki zmian stanu naprężeń ośrodka [18], widzimy, że tworzenie modelu mechanicznego ma cechy procesu „sprzężenia zwrotnego", a utworzony model musi być konsystentny w sensie współzależności parametrów.

Zmiana dynamiki w ośrodku stanowi najczęściej bezpośredni efekt eksploatacji złoża. Obniżenie ciśnienia złożowego sprawia, że ciężar nadkładu przenoszony jest na szkielet skalny (matrix), co powoduje wzrost efektywnego ciśnienia (nacisku) w złożu. W konsekwencji złoże podlega kompakcji - zmniejszeniu miąższości warstwy kolektorskiej oraz istotnemu zmniejszeniu porowatości przy jednoczesnym, ale nie zawsze oczywistym, zwiększeniu ciśnienia złożowego. Biorąc pod uwagę niejednolite opróżnianie zbiornika, niejednorodną reakcję skał nadkładu i warstw podścielających na redukcję ciśnienia porowego, w praktyce należy się liczyć z bardzo różnymi schematami zmian naprężeń i deformacji, prowadzących w konsekwencji do reaktywacji uskoków i tworzenia się szczelin.

Nie ulega wątpliwości, że wszystkie obserwowane zmiany są, zresztą w różnym stopniu, funkcją odległości od otworu eksploatacyjnego. Łatwiej je opisać w przypadku złóż eksploatowanych otworami pionowymi, dużo trudniej w przypadku otworów kierunkowych i poziomych. Już powyższa, bardzo uproszczona charakterystyka właściwości modelu geomechanicznego pozwala zrozumieć, jak ważny stanowi element w sukcesji narzędzi dla monitorowania mikrosejsmicznego. Jest faktem bezspornym, że przekroczenie stanu równowagi w ośrodku geologicznym powoduje przekroczenie relacji naprężeń, w konsekwencji następuje zerwanie continuum (ciągłości ośrodka), co manifestuje się powstaniem szczelin i uskoków. Te procesy „tektoniczne”, bez względu na ich siłę i ilość wyemitowanej energii, wywołują drgania i propagację fal sprężystych. I to stanowi początek pętli: drgania sprężyste ośrodka - naruszenie równowagi naprężeń - zdarzenia tektoniczne - ruch drgający i ponownie... drgania ośrodka... i tak dalej. Czas trwania zależy od parametrów geomechanicznych ośrodka, czyli trójwymiarowego modelu mechanicznego (MEM - mechanical earth model).

\section{Krótka charakterystyka drgań mikrosejsmicznych w aspekcie możliwości monitorowania stanu naprężeń ośrodka}

Jakie cechy drgań mikrosejsmicznych spowodowały, iż stały się one narzędziem śledzenia budowy ośrodka geologicznego w skali bardzo zminimalizowanej i specyficznej? Przyjmujemy z definicji, że drgania mikrosejsmiczne to bardzo małe trzęsienie ziemi występujące na niewielkim obszarze, wywołane przyczynami naturalnymi lub ingerencją człowieka w naturalną relację naprężeń i odkształceń istniejącą w ośrodku geologicznym. Systematyczna rejestracja pasywnych zdarzeń mikrosejsmicznych doprowadziła do znacznie lepszego zrozumienia mechanizmu źródła drgań in situ oraz reguł propagacji, a w konsekwencji do lepszego poznania procesu powstawania szczelin i uskoków w ośrodku.

Siła zdarzenia mikrosejsmicznego (magnituda $M_{w}$ ) oceniana jest w identyczny sposób jak siła trzęsień ziemi. Definiuje się ją ilościowo w ośmiostopniowej skali Richtera (gdzie naj- wyższy stopień określa trzęsienie ziemi o katastrofalnej skali zniszczenia) i opisuje relacją $M_{w}=0,67 \log _{10}\left(M_{o}\right)-6,07$ (powszechnie używana bezwymiarowa miara trzęsień ziemi). Symbol $M_{o}$ oznacza moment magnitudy i definiowany jest jako relacja energii wyemitowanej podczas ,zdarzenia sejsmicznego" oraz skutków tego zdarzenia w przestrzeni geologicznej:

$$
M_{o}=\mu \cdot A \cdot D
$$

gdzie:

$\mu$ - wytrzymałość poprzeczna skał otaczających miejsce zerwania (efekt działania zdarzenia),

$A$ - powierzchnia przesunięcia (zerwania ciągłości skały) wzdłuż uskoku lub szczeliny,

$D$ - całkowite przemieszczenie skał wzdłuż powierzchni zerwania. 
Magnituda zdarzeń mikrosejsmicznych z założenia nie powinna przekraczać wartości $4\left(M_{w} \leq 4\right)$. W efekcie przerwania ciągłości ośrodka powstają szczeliny i uskoki. Szczelina definiowana jest jako przerwanie ciągłości skały, zaś uskok - jako szczelina, w poprzek której dokonało się przemieszczenie względne skały. Dla praktycznego wyobrażenia sobie skali energii, która może być wyemitowana podczas zdarzeń mikrosejsmicznych występujących na skutek działań związanych z poszukiwaniem lub eksploatacją węglowodorów, podać można za Rie Kamei i wsp. [14], iż typowa iniekcja płynu i związana z tym zmiana ciśnienia w złożu nawet o kilka psi (kilka megapaskali) indukuje słabe zdarzenie mikrosejsmiczne o magnitudzie $M_{w}<-2$. Takie zdarzenie jest około jeden bilion razy słabsze (energetycznie) niż wstrząs, który może być odczuty przez środowisko człowieka (public).

Zdarzenie tzw. umiarkowane, które może prowadzić do reaktywacji uskoku lub znaczącego zeszczelinowania skały (przemieszczenie mniejsze niż 1 centymetr wzdłuż uskoku o długości około kilkunastu metrów), najczęściej posiada magnitudę mniejszą niż odczuwana przez środowisko (zazwyczaj $M=3 \div 4$ ). Dane mikrosejsmiczne charakteryzują się mniejszą magnitudą, wyższą częstotliwością, krótszą długością fali i krótszym czasem trwania niż w przypadku naturalnych trzęsień ziemi.

Monitorowanie mikrosejsmiczne stanowi ważne narzędzie śledzenia w ośrodku (szczególnie w trakcie procedury szczelinowania hydraulicznego) procesu przepływu płynów oraz zmiany relacji ciśnienie-naprężenie. Podobnie jak w przypadku trzęsień ziemi, lecz inaczej niż w standardowej metodzie sejsmicznej, obserwator nie może dokładnie przewidzieć czasu wzbudzenia zdarzenia sejsmicznego, jak też jego dokładnej lokalizacji; przedmiotem pomiaru jest ciągły ruch ośrodka, co teoretycznie pozwala śledzić przemieszczanie się mikrosejsmicznego pola falowego. Na podstawie zarejestrowanego pola falowego określona zostaje pozycja źródła (hipocentrum) $\{x, y, z\}$ oraz czas $t_{0} \mathrm{~W}$ źródle. $Z$ powyższych informacji można ocenić zmiany ciśnienia w ośrodku, stan zeszczelinowania oraz przestrzeń przepływu płynów złożowych. Jednakże możliwość uzyskania w tym zakresie informacji ilościowych występuje dopiero po przeprowadzeniu analizy mechanizmu źródła.

Stan naprężeń w ośrodku stałym określony jest jakościowo przez wielkość sił działających na jednostkę przestrzeni, czyli ilościowo przez tensor naprężenia $\sigma_{i j}(i=x, y, z$; $j=x, y, z$ ), wyrażony we współrzędnych kartezjańskich, czyli przez tensor ściskający $\sigma_{i j}$ prostopadły do powierzchni $\{x, y\}$ oraz przez tensor ścinający $\tau_{i j}$ równoległy do tej powierzchni (rysunek 1).

Przy założeniu symetryczności tensora naprężeń ścinających $\tau_{i j}=\tau_{y x}, \tau_{z y}=\tau_{y z}, \tau_{z x}=\tau_{x y}$ - tensor naprężeń $\sigma_{i j}$ określony

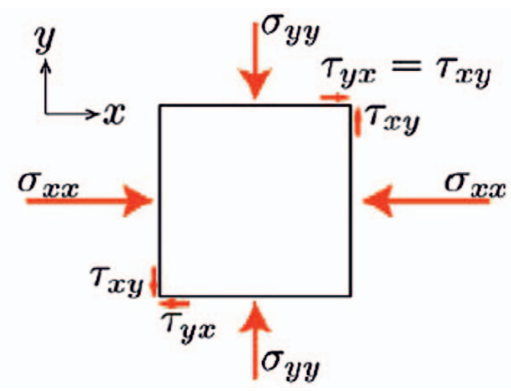

Rys. 1. Prezentacja naprężeń normalnych i stycznych na płaszczyźnie $X, Y$

jest przez sześć niezależnych składowych $\sigma_{x x}, \sigma_{y y}, \sigma_{z z}, \tau_{x y}, \tau_{y z}, \tau_{z x}$, z których trzy poprzez obrót układu wspólrzędnych można wyzerować, co powoduje redukcję do trzech składowych normalnych $\left(\sigma_{1}>\sigma_{2}>{ }_{3}\right.$ ), tzw. składowych głównych (principal component), gdzie $\sigma_{1}$ jest składową maksymalną, zaś $\sigma_{3}$ składową minimalną tensora naprężeń. Wzajemne relacje powyższych składowych głównych określają stan naprężenia w ośrodku. Powyższe zależności opisane są na podstawie diagramu kołowego Mohra-Coulomba-Griffitha (kryterium zerwania) [3].

Okrąg Mohra jest dwuwymiarową reprezentacją tensora naprężeń: wzdłuż osi horyzontalnej naprężeń prostopadłych oraz wzdłuż osi wertykalnej naprężeń stycznych - ścinających. Wzajemne relacje naprężeń normalnych i stycznych umożliwiają sformułowanie tzw. kryterium zerwania (ciągłości ośrodka), co przedstawia rysunek 2.

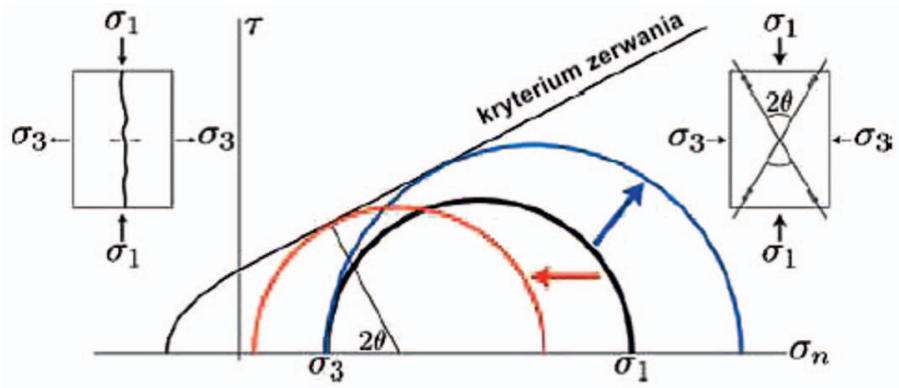

Rys. 2. Diagram kołowy Mohra oraz obwiednia wypadkowa opisująca kryterium zerwania Mohra-Coulomba-Griffitha

Oś pozioma jest osią efektywnego naprężenia normalnego $\left(\sigma_{n}\right)$, zaś oś pionowa $(\tau)$ - osią efektywnego naprężenia stycznego, poprzecznego. Prezentowany na rysunku 2 okrąg Mohra w kolorze czarnym ilustruje stabilne warunki naprężeń, natomiast okręgi czerwone i błękitne obrazują warunki zerwania wywołanego przez naprężenia niezrównoważone (rozciąganie i nacisk). Zależnie od stosunku naprężeń głównych (principal) wywołane zerwania są klasyfikowane jako przesunięcia lub zerwania ciągłości i powstanie uskoków o geometrii zależnej od wzajemnych relacji naprężeń $\sigma$ (rysunek 3). W badaniach geomechaniki oznaczane są symbolami $\sigma_{H 1},{ }_{H 2}, \sigma_{V}$. 

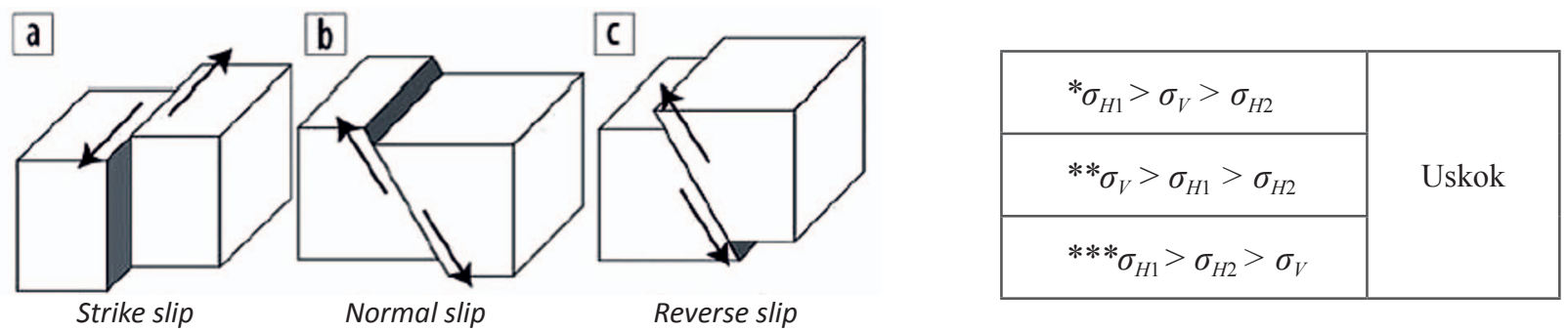

Rys. 3. Reżim tworzenia się uskoków w efekcie działania niezrównoważonego systemu naprężeń; a - przesuwczy system uskokowy (strike slip)*, $\mathrm{b}$ - normalny system uskokowy (normal slip)**, c - odwrócony system uskokowy (reverse slip) ${ }^{* * *}$

Przekroczenie krzywej obwiedni (failure criterion) przez okręgi charakteryzujące układ naprężeń prowadzi do przerwania ciągłości skał ośrodka, uwolnienia naprężeń i generowania energii będącej źródłem fal sejsmicznych. Po procesie utworzenia się uskoków ośrodek ulega skompresowaniu (compressed) lub rozprężeniu (dilatated) zależnie od relacji $\sigma_{H 1}, \sigma_{H 2}, \sigma_{V}$.

Powyższe fakty powodują z kolei, zależnie od reakcji ośrodka, wzrost lub obniżenie ciśnienia porowego oraz wzrost lub obniżenie porowatości w warstwie kolektorskiej, gdy np. obszar ma znaczny potencjał węglowodorowy. Jest to element, który stanowi pomost pomiędzy geomechanicznym modelem ziemi (badanego ośrodka) a mikrosejsmicznym monitorowaniem procesu szczelinowania hydraulicznego. Skały ośrodka, w którym wystąpił uskok (ześlizg), ulegają kompresji lub dylatacji, zależnie od ich pozycji w trakcie ruchu przesuwczego wzdłuż uskoku. W opisie jakościowym regiony kompresji i dylatacji w wizualizacji graficznej oznaczane są umownie odpowiednio kolorami czarnym i białym. Tę koncepcję zapisu nazwano koncepcją piłki plażowej (beach - ball plot). Dlatego gdy dysponujemy dostatecznie gęstym rozstawem geofonów, możemy określić mechanizm źródła na podstawie polarności (biegunowości) pierwszych wstąpień fali podłużnej P.

Praktyka monitorowania mikrosejsmicznego dzięki nowym aspektom w spojrzeniu na mechanizm źródła znajduje zastosowanie nie tylko w poszukiwaniu węglowodorów, ale też m.in. wód termalnych, gruntowych, sekwestracji $\mathrm{CO}_{2}$.

\section{Monitorowanie mikrosejsmiczne - zamierzenia a praktyka}

Monitorowanie zachowania obiektów typu złoża niekonwencjonalne jest procesem dynamicznym. Bez względu na to, z jakim obiektem mamy do czynienia, ważne jest, aby śledzić zmienność w czasie, np. w trakcie procesu udostępniania złoża, szczelinowania czy eksploatacji. Złoża niekonwencjonalne, a szczególnie te występujące w formacjach łupkowych, wymagają rozwiązań odmiennych od standardowych, zarówno w dziedzinie akwizycji, jak też udostępniania i eksploatacji. Wynika to między innymi z charakterystyki lokalizacyjnej tych złóż. Podatność ośrodka na szczelinowanie hydrauliczne, czyli możliwość tworzenia nowej sieci szczelin, powinna być oceniana przed i w trakcie procesu szczelinowania. Najskuteczniejszą znaną i stosowaną metodą w tym zakresie jest właśnie mikrosejsmika.

W problematyce powyższej należy wymienić przede wszystkim dwie technologie: technologię sejsmiki pasywnej (passive seismic monitoring) - wykorzystanie zjawiska drgań mikrosejsmicznych oraz technologię sejsmiki 4D. W monitorowaniu wykorzystujemy źródło drgań działające w procesie technologicznym (wiercenie, szczelinowanie), a więc wewnątrz ośrodka. Najczęściej komentowane badania mikrosejsmiczne występują w trzech modyfikacjach (rysunek 4):

1. Monitorowanie otworowe (downhole monitoring) opcja możliwa do realizacji, jeżeli monitorowany obszar posiada otwór (otwory) monitorujący nie dalej niż $300 \mathrm{~m}$ ( 1000 stóp) od przewidywanego źródła drgań. Opcja relatywnie mało kosztochłonna.

2. Monitorowanie rozstawem powierzchniowym (surface array monitoring) - opcja chroniona patentem, przeznaczona specjalnie do monitorowania dużych obiektów i dużych powierzchni z wieloma otworami, ale bez otworu monitorującego. Również w przypadku, gdy dla danych otworowych nie ma możliwości ponownego uruchomienia produkcji.

3. Monitorowanie rozstawem pogrążonym (buried array), czyli w układzie geofonów dość płytko umieszczonych w ziemi. Opcja pomyślana specjalnie do długiego okresu monitorowania rozległego zbiornika o dużej perspektywie rozwoju.

Obraz pola mikrosejsmicznego generowanego w procesie szczelinowania hydraulicznego stanowi znacznie trudniejszy obiekt do interpretacji w porównaniu z typowym polem sejsmicznym, uzyskiwanym podczas standardowych prac sejsmicznych 2D czy też 3D. Podczas prac sejsmicznych, mając założony schemat obserwacji, niewiadomą stanowi obiekt geologiczny. Natomiast podczas szczelinowania hydraulicznego wcale nie jest określone, że źródłem drgań mikrosejsmicznych będzie dokładnie punkt szczelinowania, stąd 
nie można powiedzieć, że dokładnie znamy położenie źródła. W takim przypadku znajomość sytuacji alternatywnych odgrywa bardzo istotną rolę. Modelowanie stwarza możliwość rozważenia wielu rozwiązań. a)

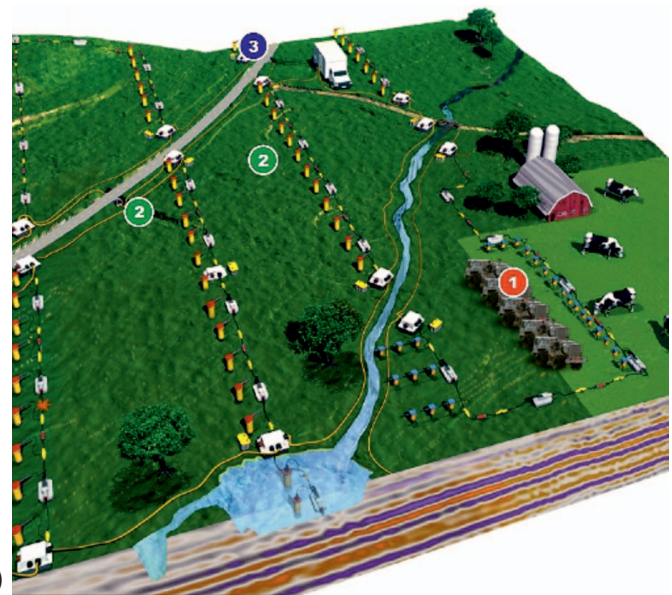

b)

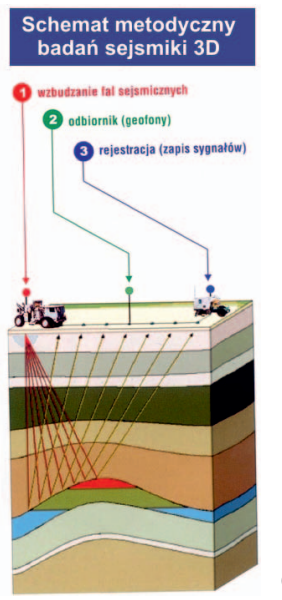

c)

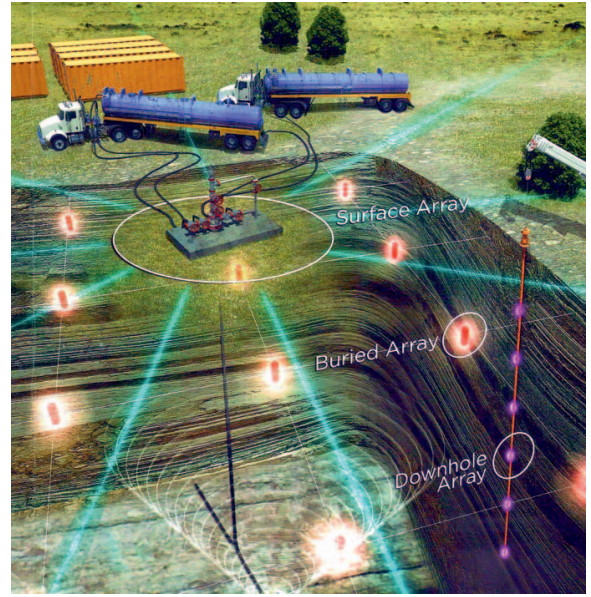

Rys. 4. Rozstaw sejsmiczny (a) i idea propagacji drgań sprężystych w ośrodku (b). Schematy akwizycji wykorzystywane w monitorowaniu mikrosejsmicznym (c)

Surface array - rozstaw powierzchniowy, buried array - rozstaw pogrążony (wgłębny), downhole array - rozstaw w otworze pionowym

\section{Modelowanie mikrosejsmiczne jako sposób predykcji parametrów geometrycznych szczelinowania hydraulicznego oraz monitorowania efektów udostępnienia niekonwencjonalnych obiektów złożowych}

Różnorodność zagadnień, które należy rozważyć przed rozpoczęciem szczelinowania hydraulicznego, skłoniła wykonawców jednego z zadań (pt. Przetwarzanie i interpretacja danych mikrosejsmicznych oraz symulacje numeryczne fal generowanych $w$ procesie szczelinowania hydraulicznego, w tym mikrosejsmika - aktywna i pasywna - w celu określenia dynamicznych zmian $w$ ośrodku wywołanych procesami udostępniania i eksploatacji formacji łupkowych) projektu GASŁUPMIKROS do opracowania koncepcji algorytmu rozwiązującego problem modelowania mikrosejsmicznego (dla mikrosejsmiki) ogólnie, możliwie wszechstronnie.

Numerycznym rozwiązaniem algorytmu jest program MIKROMOD 3D FRACTURES, przeznaczony do modelowania pola sejsmicznego - mikrosejsmicznego, powstającego na skutek drgań ośrodka wywołanych procesem szczelinowania hydraulicznego. W algorytmie wykorzystano zasady dynamicznej teorii propagacji drgań sprężystych [29]. Drgania te posiadają (w porównaniu z drganiami powstającymi podczas standardowego wzbudzania w metodzie sejsmicznej) stosunkowo niewielką energię (i magnitudę), stąd obserwacja ich stanowiła i nadal stanowi poważne wyzwanie. Trudno byłoby zapisać relację, która w sposób dokładny opisuje zależność charakterystyki kinematycznej i dynamicznej tych drgań od parametrów ośrodka i od odległości od źródła drgań (położenia sukcesywnie rozprzestrzeniających się szczelin), pomimo że równania fal sprężystych są znane od dziesiątek lat. Algorytm programu został opracowany w taki sposób, aby można było symulować każdy z trzech najczęściej stosowanych sposobów monitorowania mikrosejsmicznego, tzn. monitorowanie powierzchniowe, otworowe oraz odbiorników pogrążonych.

\section{Tworzenie trójwymiarowych modeli testowych}

Wstępną koncepcję modelowania trójwymiarowego 3D przedstawia poniższa sekwencja (rysunek 5).

Ilustracją tablicy wyników są wykresy (rysunek 6), na których przedstawiono wartości całkowitej drogi promienia $R[\mathrm{~km}$ ] oraz czasu propagacji $T$ [s] (czas pojedynczy) w zależności od przyjętych parametrów sterowania propagacją promienia w przestrzeni (kąt azymutu $f i$ [st] oraz wielkość promienia sterującego $\left.r_{i}[\mathrm{~km}]\right)$. Dla przyjętych do obliczeń parametrów (tablica 1 wyników KATBETAC) i przyjętych wartości promienia sterującego w zakresie od $100 \mathrm{~m} \mathrm{do}$ $\underline{1000 \mathrm{~m}}$, jak też dla pełnego kąta azymutu w zakresie od $0^{\circ}$ do $360^{\circ}$ całkowita droga promienia różni się o około $1 \mathrm{~km}$, zaś czas propagacji o około $600 \mathrm{~ms}$ - i o około $400 \mathrm{~m}$ oraz około 300 ms w zależności od kolejności zadanych prędkości (wersja WUA i wersja WUB).

Analogicznie wykresy dla promieni sterujących $r=3000 \mathrm{~m}$ i $r=5000 \mathrm{~m}$ pokazują, jak istotny wpływ na wyniki pomiarów mikrosejsmicznych ma proporcja głębokości obiektu szczelinowanego oraz usytuowanie kolejnych zespołów pomiarowych. 


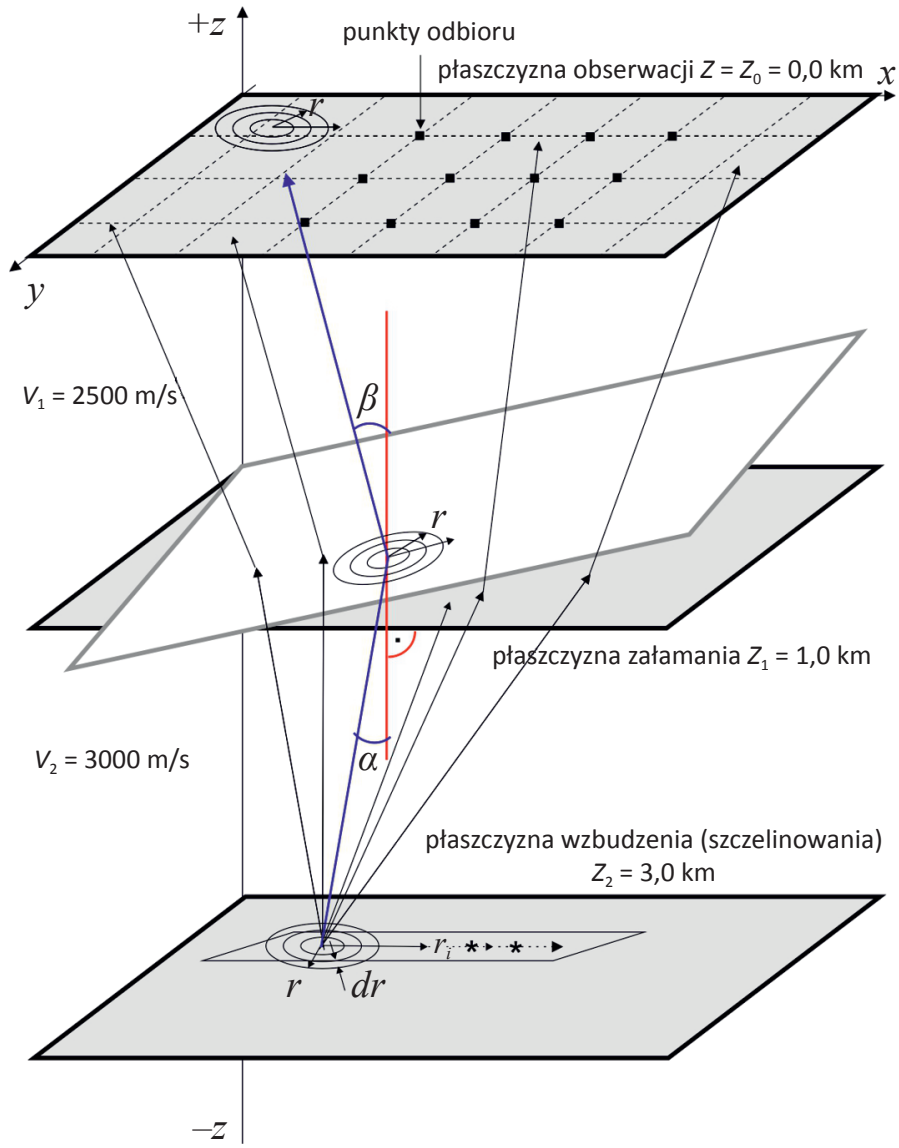

Rys. 5. Koncepcja rozwiązania geometrii i akwizycji przestrzennego modelowania 3D

Ograniczona kierunkowo wiązka rozprzestrzeniających się promieni sejsmicznych trafia na wybrany fragment powierzchni obserwacji o zadeklarowanych współrzędnych, gdzie umieszczone są urządzenia rejestrujące (geofony).
Przestrzeń obiektu geologicznego jest opisana trzema powierzchniami (płaszczyznami): $Z_{0}, Z_{1}, Z_{2}$ o następującym przyporządkowaniu:

$Z_{0}$ - powierzchnia ziemi określona jako powierzchnia (płaszczyzna) odbioru

[zbiór punktów PO $\left(X_{i}=0, Y_{i}=0, Z_{i}=0\right)$ ],

$Z_{1}$ - dowolna powierzchnia $\mathrm{w}$ ośrodku geologicznym określona jako powierzchnia (płaszczyzna) załamania

[zbiór punktów $\mathrm{PZ}\left(X_{i i}=0, Y_{i i}=0, Z_{i i}=1\right)$ ],

$Z_{2}$ - powierzchnia w ośrodku geologicznym określana jako powierzchnia (płaszczyzna) wzbudzenia [zbiór punktów $\mathrm{PW}\left(X_{i i}=0, Y_{i i}=0, Z_{i i}=3\right)$ ].

Dwie warstwy geologiczne ograniczone powierzchniami $Z_{0}-Z_{1}-Z_{2}$ opisane są wartościami prędkości $V_{1}$ i $V_{2}$ gdzie: $V_{1}\left(\right.$ granice $\left.V_{0}-V_{1}\right)$ oraz $V_{2}\left(\right.$ granice $\left.V_{1}-V_{2}\right)$ - rysunek 5.

Na powierzchni wzbudzenia $\{\mathrm{W}\}$ wybierany jest punkt (środek okręgu), z którego w pełnym zakresie azymutów propaguje do powierzchni $Z_{0}$ fala sprężysta.

Dla uzyskania efektu ogniskowania energii i wyeliminowania (w modelowaniu) nadmiernego rozproszenia punktów obserwacji wprowadzona zostaje umowna płaszczyzna załamania, która umożliwia ograniczenie obszaru akwizycji do geologicznie uzasadnionych rozmiarów.

Sekwencja obliczeń jest następująca (tablica 1):

- dla zadanego początkowego (startowego PS $\left(X_{0}=0, Y_{0}=0, Z_{0}=3,0\right)$ ) punktu wzbudzenia deklaruje się okręgi o zadanym promieniu $r[\mathrm{~km}]$ (zgodnie z krokiem $d r[\mathrm{~km}]$ ) i oblicza się współrzędne kolejnych punktów wzbudzenia zlokalizowanych na okręgach o założonych azymutach $f($ st) [kolumny $\left.f i, X_{0}, Y_{0}, Z_{0}\right]$,

- dla zadeklarowanego punktu załamania ustala się zakres kątów padania i załamania w odniesieniu do prostopadłej do płaszczyzny załamania

[kolumny alfa (st), beta (st)],

- w zależności od przyjętych kątów padania-załamania oblicza się współrzędne punktów obserwacji (rejestracji) na powierzchni $z=0,00 \mathrm{~km}$ oraz całkowitą drogę i czas propagacji [kolumny $x[\mathrm{~km}], y[\mathrm{~km}], z=2 \mathrm{~km}, R[\mathrm{~km}], T[\mathrm{~s}]]$.

W przypadku granic płaskorównoległych, nazywanych w wersji roboczej opcjami WUA i WUB - w zależności od sposobu zadania prędkości, potwierdza się oczywista symetria funkcji $T(f i)$ oraz $R(f i)$ w stosunku do kąta obserwacji $180^{\circ}$, zarówno w przypadku propagacji „w górę", jak i „w dół”. Przy wprowadzeniu parametrów anizotropii (opcja WIN: $v\left(f i=0\right.$ i $\left.180^{\circ}\right) \neq v\left(f i=90^{\circ}\right.$ i $\left.\left.270^{\circ}\right)\right)$ droga propagacji pozostaje niezmieniona, zmienia się oczywiście czas propagacji.

Opisana wyżej pierwsza edycja programu MIKROMOD 3D potwierdziła poprawność zaproponowanego rozwiązania i skłoniła autorów (Halina Jędrzejowska-Tyczkowska, Krystyna Żukowska, lata 2014, 2015) do uogólnienia koncepcji, zarówno 
Tablica 1. Ilustracja organizacji wyników obliczania (a) promienia $R[\mathrm{~km}]$ i (b) czasu $T$ [s] propagacji drgań mikrosejsmicznych: PO - punkt odbioru, PS (PW) - punkt wzbudzenia, PZ - punkt złamania

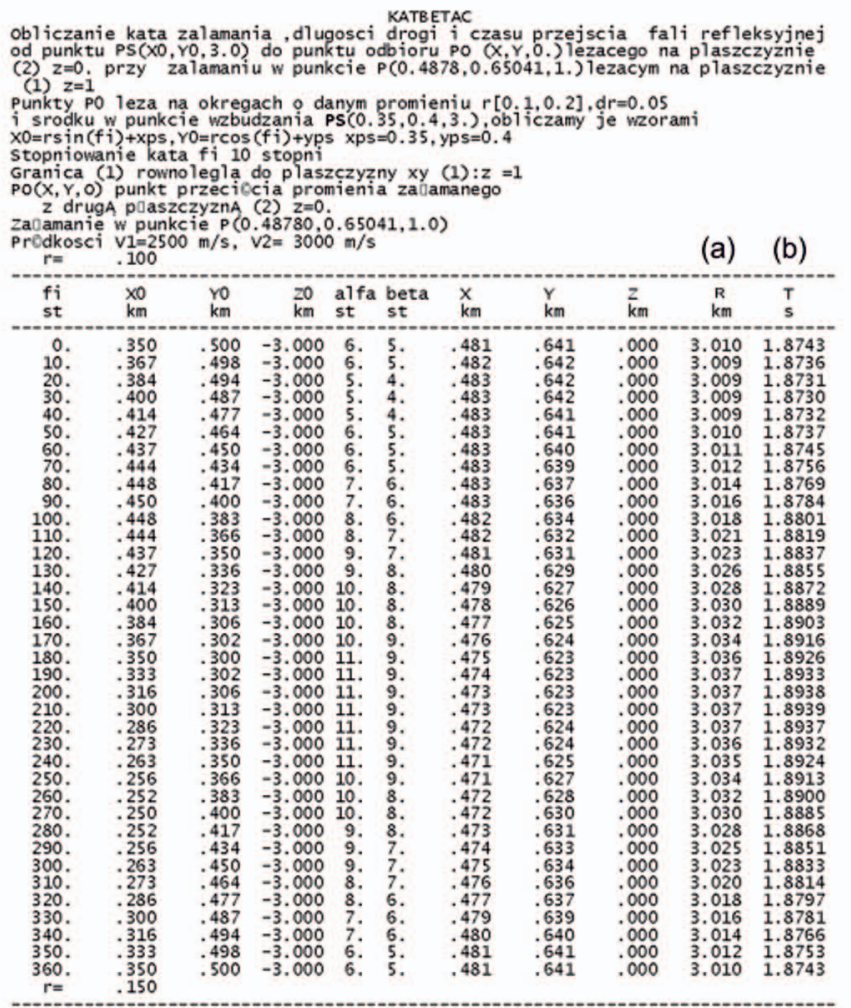

w zakresie geometrii modelu ośrodka geologicznego, jak i schematu szczelinowania hydraulicznego (traktowanego jako sposób wzbudzania drgań sprężystych) oraz sposobu monitorowania mikrosejsmicznego wraz z ulokowaniem i wskazaniem schematu akwizycji. Program umożliwia obecnie dowolne, zgodne z potrzebami inwestora, zaprojektowanie systemu akwizycji, co przedstawione zostało na kolejnych modelach.

Schemat logiczny rozbudowanego systemu modelowania przedstawia się następująco (rysunki 7a, b, c):

\section{(a) DEKLARACJA MODELU}

\section{Wprowadzenie parametrów modelu:}

- liczba powierzchni rozgraniczających warstwy geologiczne

- współczynniki równania powierzchni aproksymowanych płaszczyznami (w kolejności granic): A, B, C, D dla relacji $A x+B y+C z+D=0$

- wartości prędkości sejsmicznych w sekwencji „od góry”: $V[\mathrm{~m} / \mathrm{s}]$ oraz $\rho\left[\mathrm{g} / \mathrm{m}^{3}\right]$

\section{Deklaracja kierunku propagacji:}

- przebieg promienia w dół (D - down)

- $\quad$ przebieg promienia w górę $(\mathrm{U}-u p)$
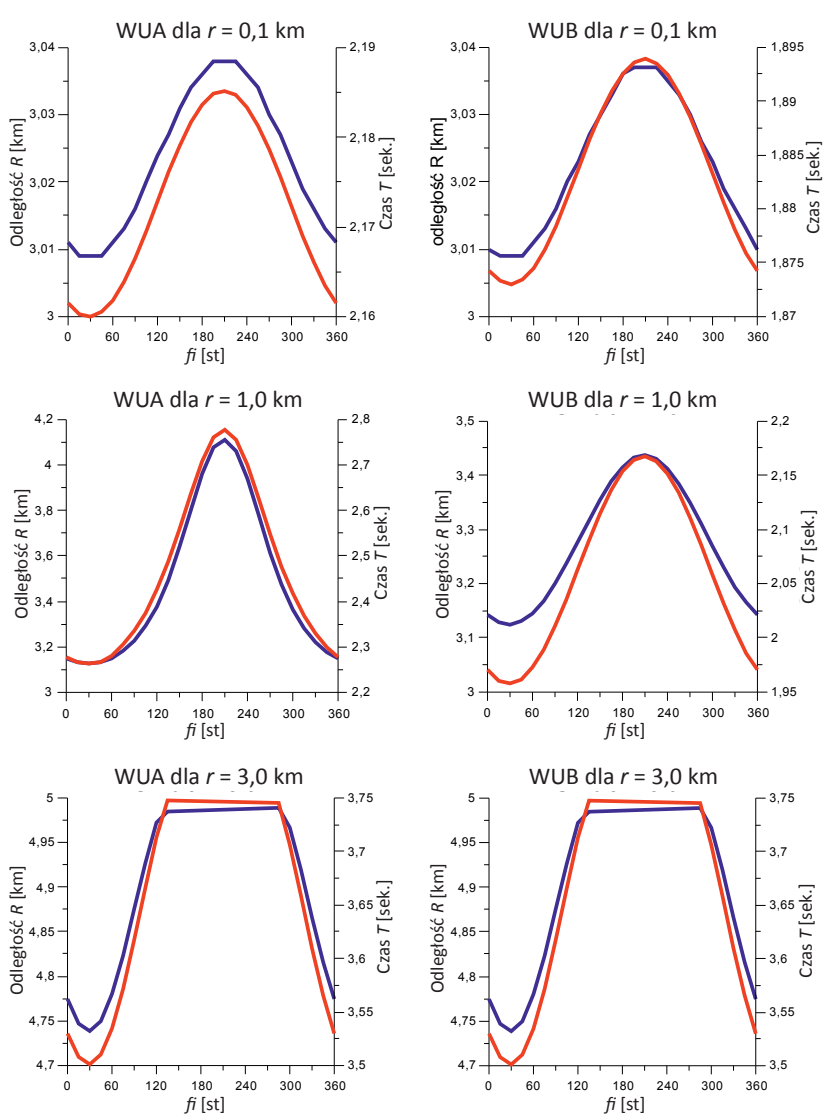
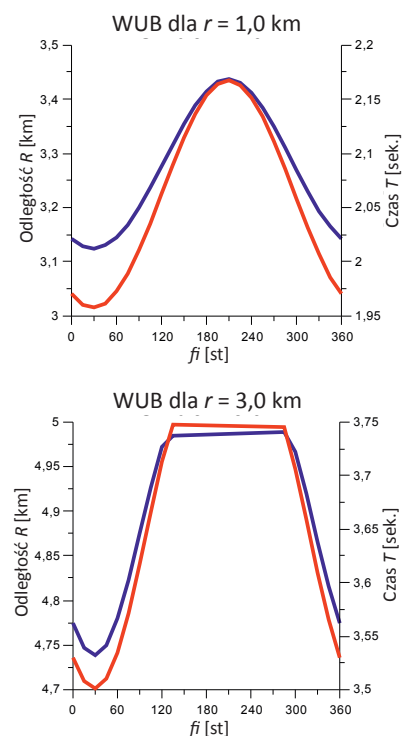
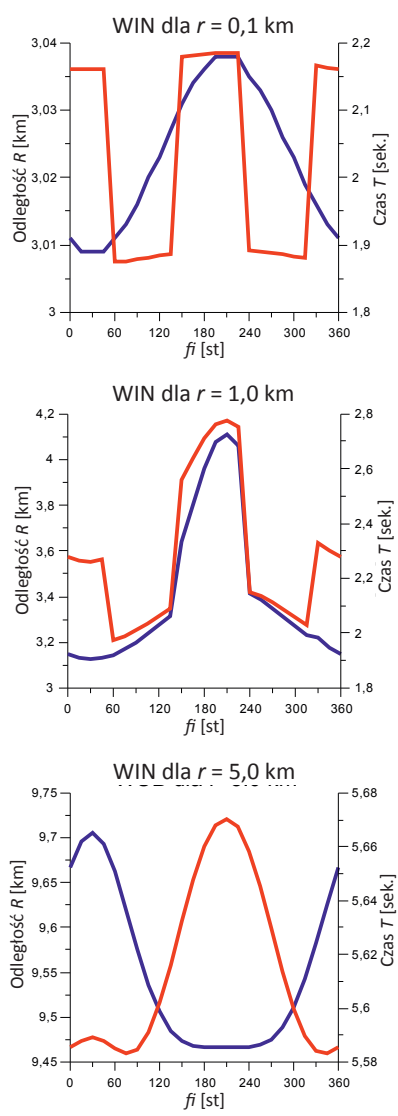

Legenda:

WUA, WUB - sposób zadania prędkości [m/s] (wyróżnienie wartości np. WUA: $V 1=25$

$V_{i}(1, \ldots, j)$ - zawsze w taki sposób, że $V_{1}$ jest bezpośrednio pod powierzchnią ziemi (warstwa $\left.z=z_{0}=0,0 \mathrm{~m}\right)$

WIN - sposób zadania anizotropii (w zależności od kąta fi)

$r$ - promień okręgu wyjściowego (sterującego) $T(f i)$ - czas propagaci

Rys. 6. Wykresy wyników obliczeń drogi $R(f i)$ i czasu $T(f i)$ drgań mikrosejsmicznych w zależności od położenia źródła drgań w stosunku do położenia rozstawu rejestrującego 
Określenie parametrów $\{X, Y, Z\}$ punktów wzbudzenia i załamania, w zależności od kierunku propagacji

Deklaracja zakresu rejestracji (opcyjnie):

- obszar rejestracji z ograniczeniami np.

$0,00<x[\mathrm{~km}]<15,00$

$0,00<y[\mathrm{~km}]<15,00$

- obszar rejestracji bez ograniczeń

Deklaracja sposobu obliczenia thumienia energii E:

- relacja teoretyczna $E=f(R)$

gdzie: $f$ - postać analityczna zależności energii od odle-

głości od punktu wzbudzenia

$R$ - całkowita długość promienia

- aproksymacja wyników rzeczywistych rejestracji polowych $E(R)$

Obliczenie współczynników odbicia na podstawie parametrów $V, \rho$ analizowanego modelu:

\begin{tabular}{|c|c|c|}
\hline Nr warstwy & $V[\mathrm{~m} / \mathrm{s}]$ & $\rho\left[\mathrm{g} / \mathrm{m}^{3}\right]$ \\
\hline 1 & 2600 & 2,14 \\
\hline 2 & 3000 & 2,35 \\
\hline 3 & 3500 & 2,40 \\
\hline 4 & 4000 & 2,35 \\
\hline
\end{tabular}

Wprowadzenie parametrów realizacji obliczeń:

- wielkość promienia wiodącego (odległość od punktu wzbudzania) i zakres zmiany $r_{i}$ :

$r p$ - punkt początkowy, $r k$ - punkt końcowy, $d r$ - krok zmiany promienia

- zakres zmiany azymutu obliczeń fii:

fip - kąt początkowy, fik - kąt końcowy, dif - zakres zmian kąta

- organizacja wyników

\section{(b) EGZEKUCJA PROGRAMU I WYPROWADZENIE WYNIKÓW (FRAGMENTY)}

Dane wejściowe i tabela wyników programu MIKROMOD 3D (na przykładzie modelu 2)

Propagacja „w dół”

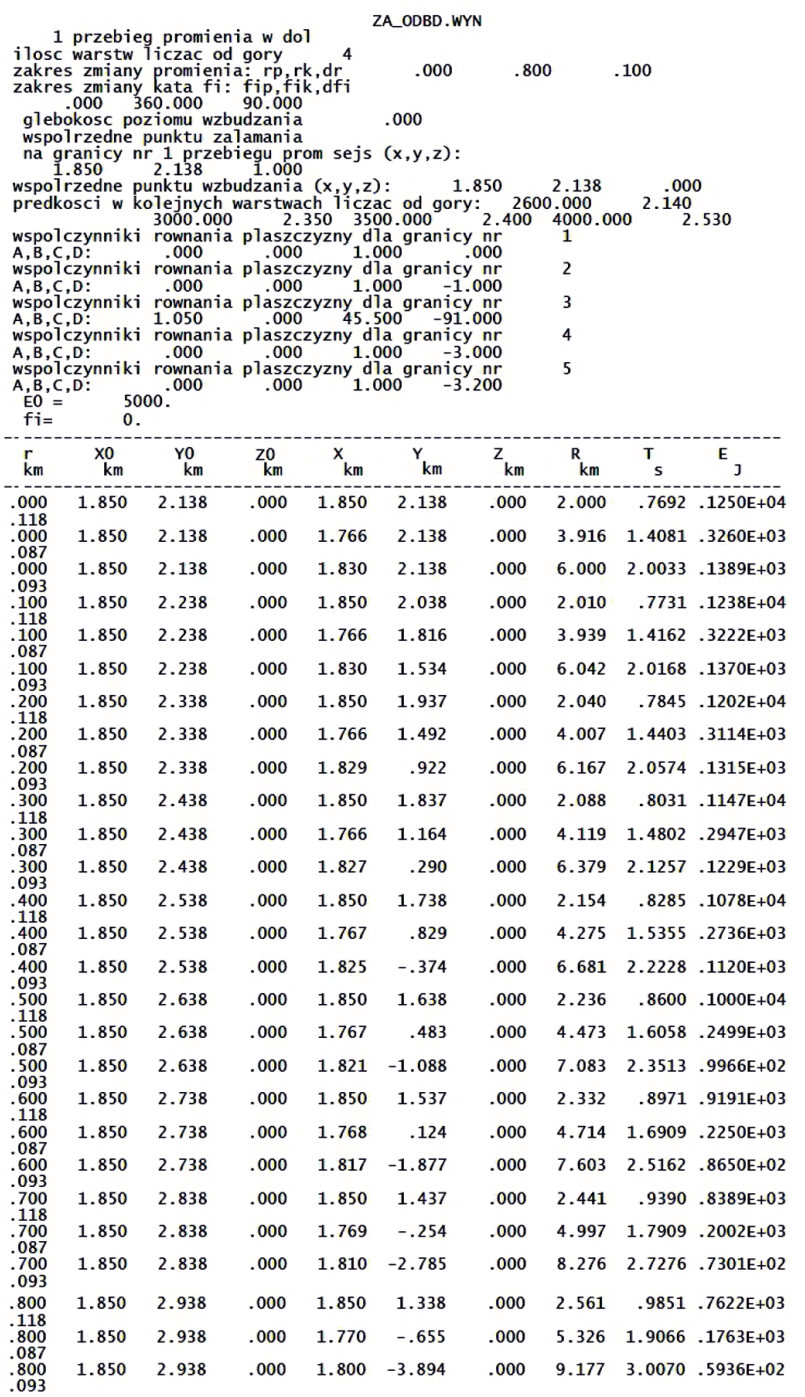

Propagacja ,w górę”

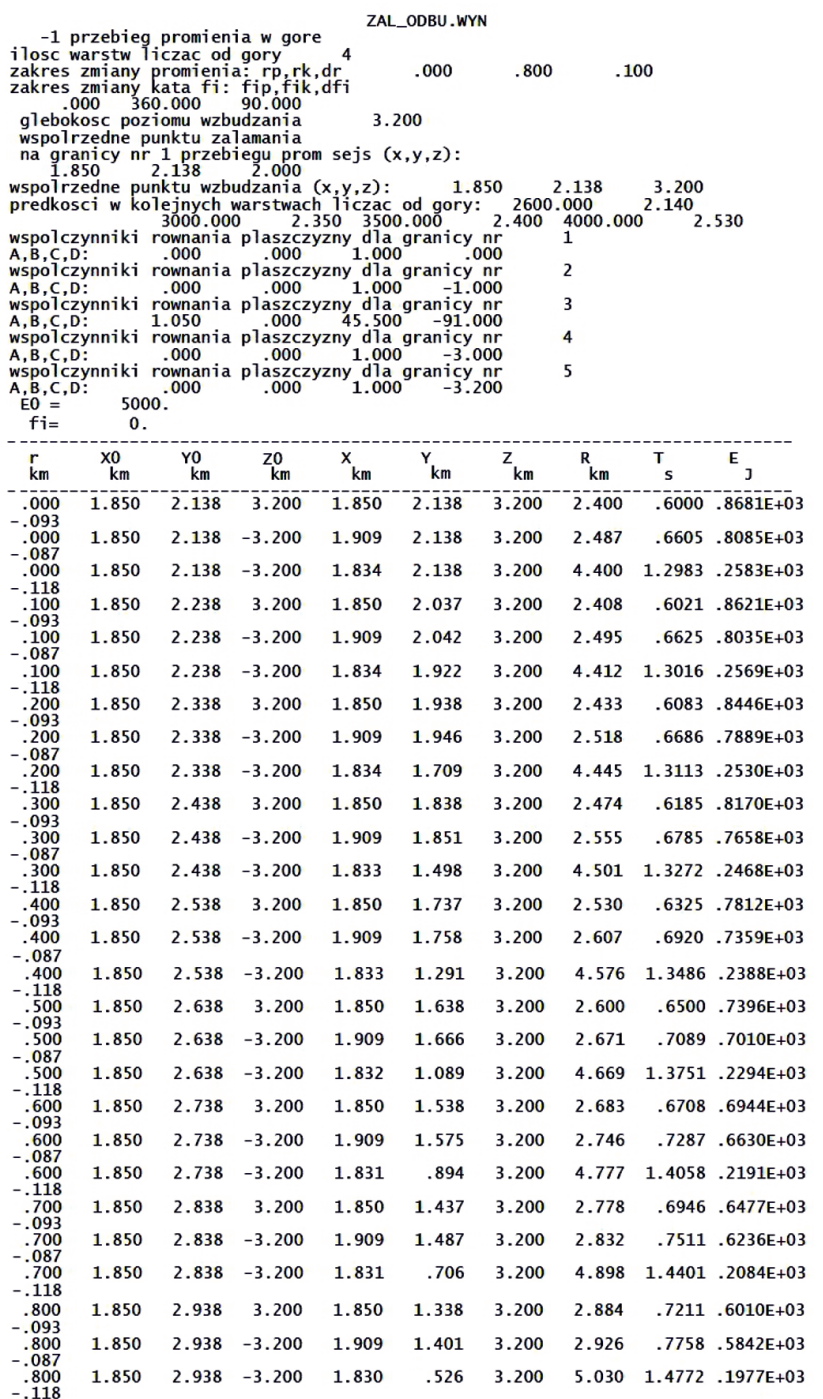


(c)

\section{WIZUALIZACJA WYNIKÓW}

Sukcesja granic
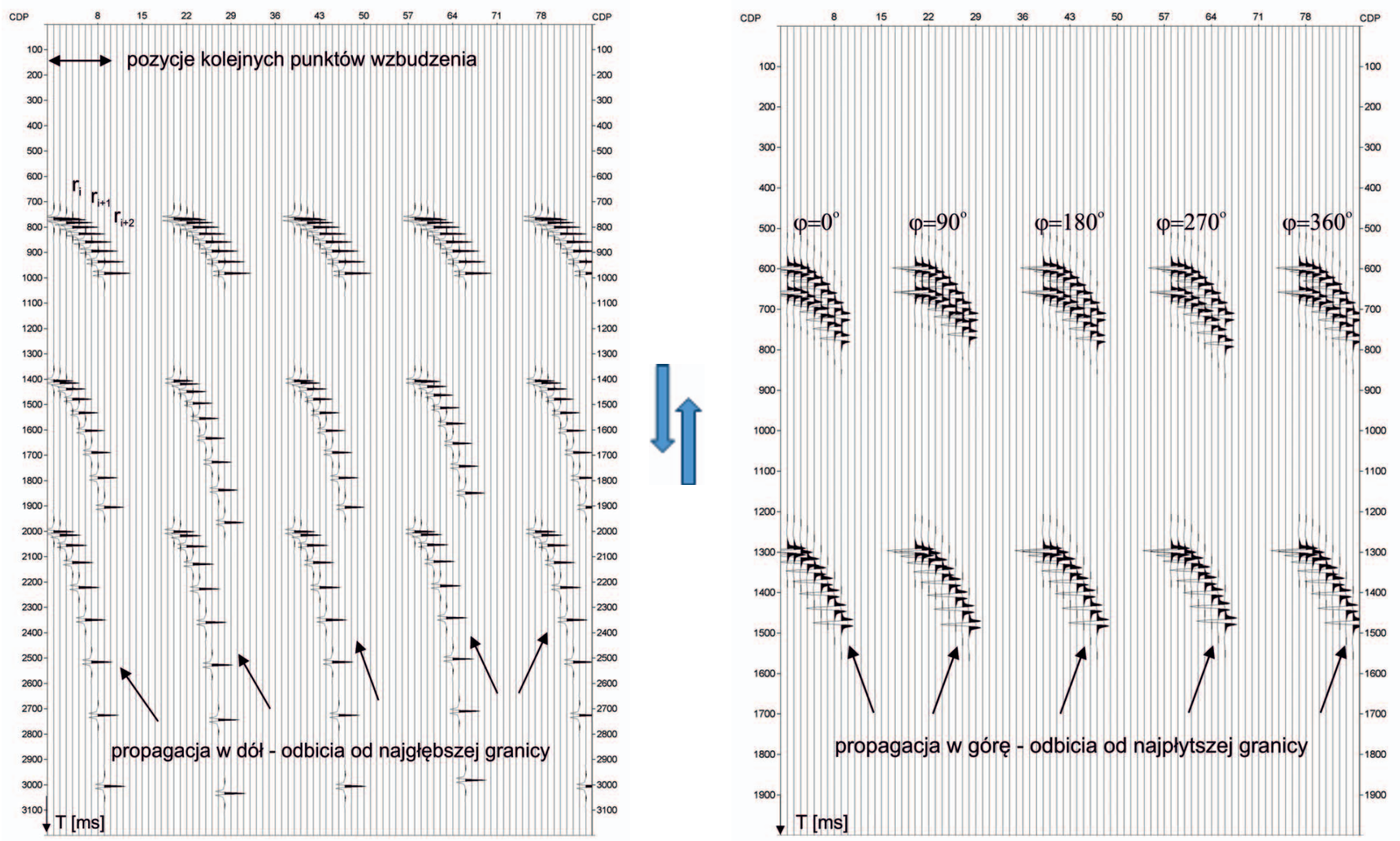

Rys. 7. Schemat realizacji programu MIKROMOD 3D:

wprowadzenie danych (a), tablice wyników (b) i prezentacja graficzna wyników (c)

Celem dość szczegółowego przedstawienia parametrów programu oraz sposobu ich wprowadzenia jest pokazanie specyfiki deklarowania powierzchni modelu (co ma bardzo duże znaczenie dla czasochłonności obliczeń), bowiem zachowane muszą być rozsądne proporcje pomiędzy szczegółowością opisu modelu, przybliżeniem wykorzystanych reguł matematycznych a szczegółowością uzyskanych wyników odniesionych do rozmiarów modelu i ewentualnego efektu skali. I tak, wprowadzenie dodatkowych informacji o deklaracji punktów załamania nie stanowi objaśnienia na temat definicji punktu załamania, ale sygnalizuje pomysł ograniczenia wiązki emitowanych „promieni” w zależności od wielkości zadeklarowanej powierzchni obserwacji. Podobną motywacją, związaną ze stopniem rozpoznania obiektu badań oraz lepszym lub gorszym powodzeniem eksperymentów i pomiarów polowych, podyktowana jest propozycja wprowadzenia różnych reguł tłumienia energii, które łatwo można będzie dostosować do realnie zarejestrowanych wielkości. Budowa przestrzennego modelu geologicznego silnie rzutuje na czasochłonność realizacji programu, bowiem tzw. trasowanie promienia sejsmicznego, obliczenie całko- witej drogi i czasu propagacji, wymaga ciągłego sprawdzania sukcesji granic i właściwego doboru prędkości propagacji w kolejnych warstwach.

Na rysunku 8 przedstawiono najprostszy przypadek tworzenia modelu, z jedną powierzchnią nachyloną zadaną trzema punktami: $P_{1}, P_{2}, P_{3}$ (model 1).

Wybór takiego sposobu deklarowania powierzchni (aktualnie płaszczyzny, zadanej wielomianem pierwszego stopnia $A x+B y+C z+D=0$ ) symuluje uzyskanie informacji o głębokości zalegania danej formacji na podstawie danych otworowych (borehole).

Nieco bardziej skomplikowany przypadek stanowi model 2 (rysunek 9), dla którego zdefiniowano, zgodnie z przyjętą kolejną koncepcją - jak na rysunku 7, pięć powierzchni rozgraniczających kolejne warstwy w ośrodku. Jak wspomniano, powierzchnie aproksymowane są wielomianami pierwszego stopnia charakteryzującymi płaszczyzny. Pierwsza powierzchnia, określająca tzw. swobodną powierzchnię (free surface), to granica ziemia-powietrze, o współrzędnej pionowej $z_{1}=0$. Kolejne powierzchnie: druga, czwarta i piąta są wzajemnie równoległe $\left(z_{2}=1 \mathrm{~km}, z_{4}=3 \mathrm{~km}, z_{5}=3,2 \mathrm{~km}\right)$. 


\begin{tabular}{|c|r|c|c|}
\hline \multirow{2}{*}{ Nr punktu } & \multicolumn{3}{|c|}{ Współrzędna } \\
\cline { 2 - 4 } & $x$ & $y$ & $z$ \\
\hline$P_{1}$ & 0,0 & 0,0 & 2,0 \\
\hline$P_{2}$ & 13,0 & 0,0 & 1,7 \\
\hline$P_{3}$ & 3,0 & 3,5 & 2,0 \\
\hline
\end{tabular}

Wyznaczanie trzech zadanych punktów:
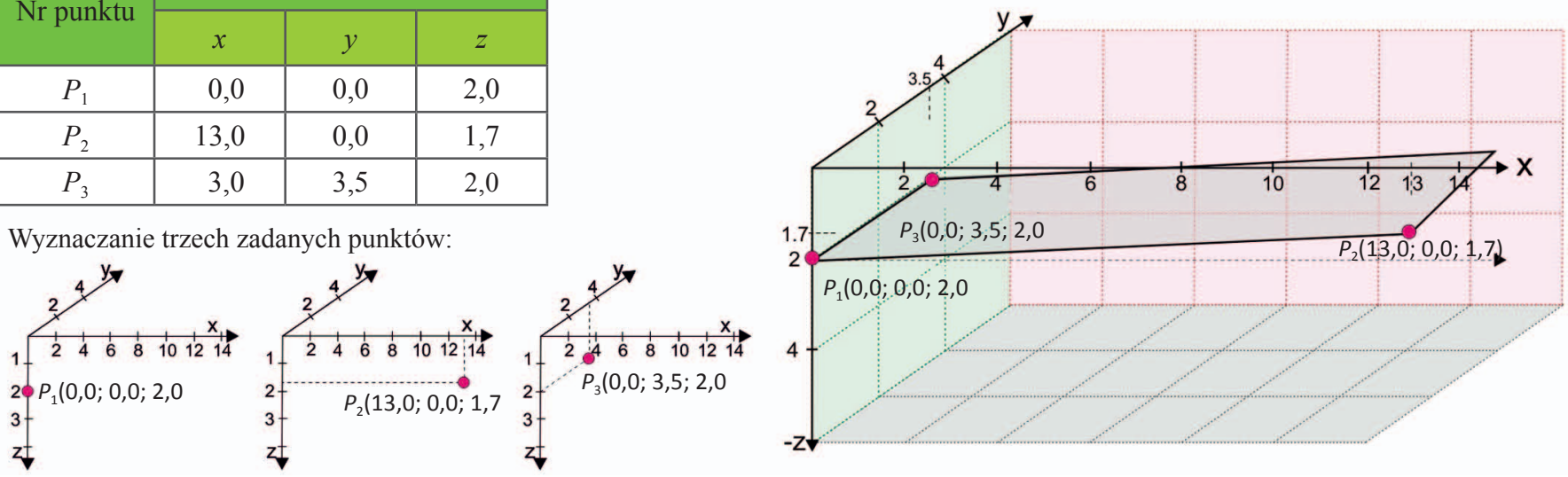

Rys. 8. Model 1. Sekwencja tworzenia modelu przestrzennego z jedną powierzchnią nachyloną, zgodnie z zaproponowaną wcześniej koncepcją (rysunek 5)

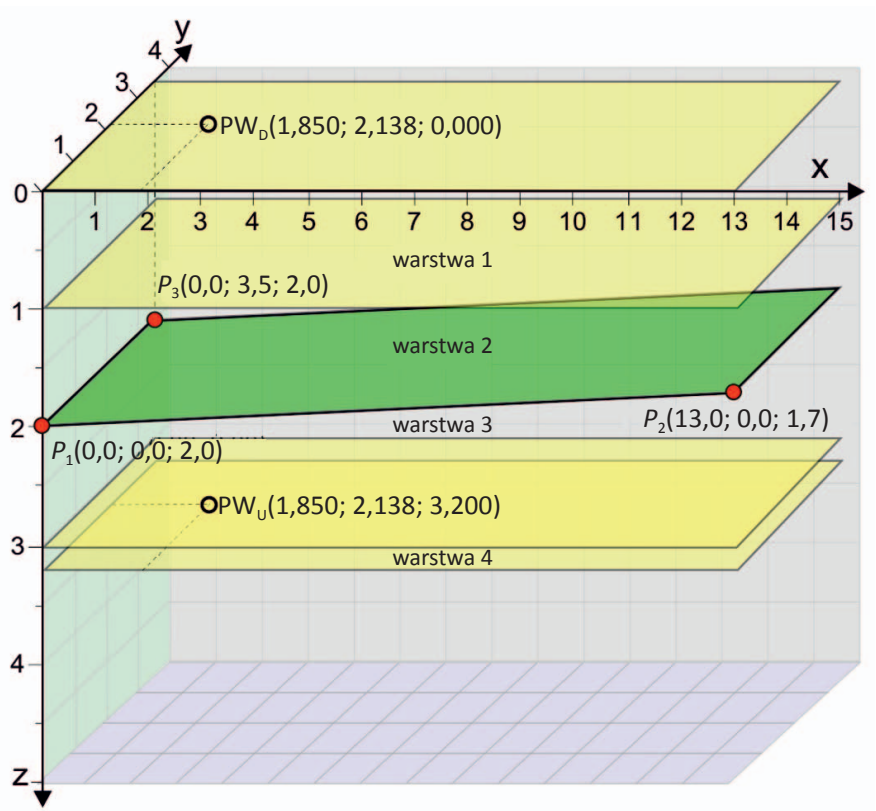

Powierzchnie modelu 2 opisano równaniami, jak niżej:

\begin{tabular}{|c|c|c|c|c|c|c|}
\hline Powierzchnia & $A x$ & $+B y$ & $+C z$ & $+D$ & $=0$ & \\
\hline 1 & 0,0 & 0,0 & 1,0 & 0,0 & & $z=0$ \\
\hline 2 & 0,0 & 0,0 & 1,0 & $-1,0$ & & $z=-1$ \\
\hline 3 & 1,05 & 0,0 & 45,5 & $-91,0$ & & $\begin{array}{l}\text { granica nachylona } \\
1,7 \leq z \leq 2\end{array}$ \\
\hline 4 & 0,0 & 0,0 & 1,0 & $-3,0$ & & $z=-3$ \\
\hline 5 & 0,0 & 0,0 & 1,0 & $-3,2$ & & $z=-3,2$ \\
\hline
\end{tabular}

natomiast prędkości i gęstości są następujące:

\begin{tabular}{|c|c|c|}
\hline Nr warstwy & $V[\mathrm{~m} / \mathrm{s}]$ & $\rho\left[\mathrm{g} / \mathrm{m}^{3}\right]$ \\
\hline 1 & 2600 & 2,14 \\
\hline 2 & 3000 & 2,35 \\
\hline 3 & 3500 & 2,40 \\
\hline 4 & 4000 & 2,35 \\
\hline
\end{tabular}

Rys. 9. Geometria modelu 2 (liczba warstw: 4; liczba powierzchni rozgraniczających: 5)

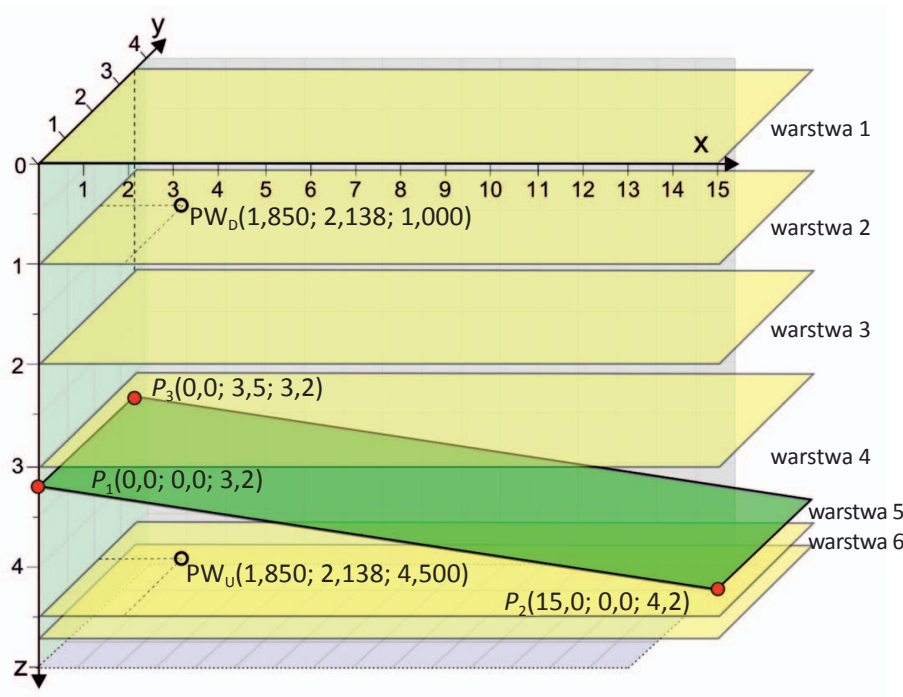

\begin{tabular}{|c|c|c|c|c|c|}
\hline Powierzchnia & $A x$ & By & $C z$ & $D$ & \\
\hline 1 & 0,0 & 0,0 & 1,0 & 0,0 & $z=0 \mathrm{~km}$ \\
\hline 2 & 0,0 & 0,0 & 1,0 & $-1,0$ & $z=-1$ \\
\hline 3 & 0,0 & 0,0 & 1,0 & $-2,0$ & $z=-2$ \\
\hline 4 & 0,0 & 0,0 & 1,0 & $-3,0$ & $z=-3$ \\
\hline 5 & $-3,5$ & 0,0 & 52,5 & $-168,0$ & $\begin{array}{l}\text { granica nachylona } \\
3,2 \leq z \leq 4,2\end{array}$ \\
\hline 6 & 0,0 & 0,0 & 1,0 & $-4,5$ & $z=-4,5$ \\
\hline 7 & 0,0 & 0,0 & 1,0 & $-4,7$ & $z=-4,7$ \\
\hline
\end{tabular}

Granicę nachyloną określono na podstawie trzech punktów:

\begin{tabular}{|c|c|c|c|}
\hline Nr punktu & $x$ & $y$ & $z$ \\
\hline$P_{1}$ & 0,0 & 0,0 & 3,2 \\
\hline$P_{2}$ & 15,0 & 0,0 & 4,2 \\
\hline$P_{3}$ & 3,0 & 3,5 & 3,2 \\
\hline
\end{tabular}

Rys. 10. Geometria modelu 3 (liczba warstw: 6; liczba powierzchni rozgraniczających: 7) 
Tablica 2. Tablica deklaracji parametrów dla programu MIKROMOD 3D - propagacja w dół (a), propagacja w górę (b) - w opcji z ograniczeniem obszaru rejestracji dla modelu 3

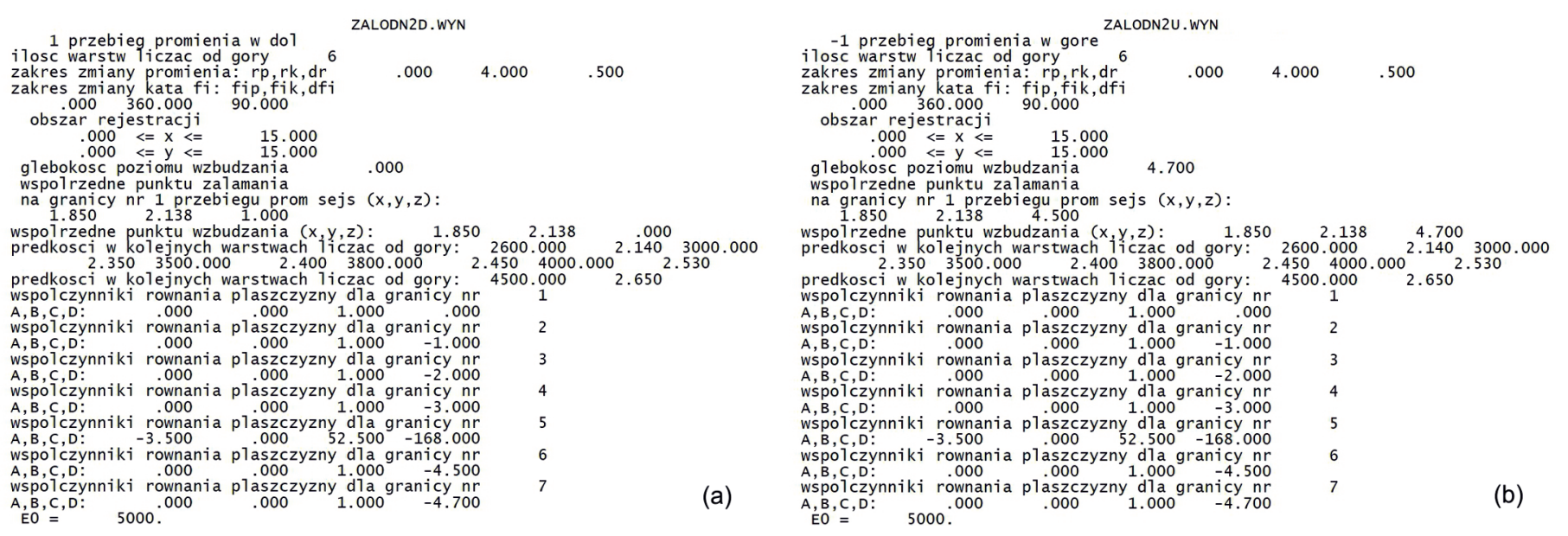

Tablica 3. Tablica deklaracji parametrów dla programu MIKROMOD 3D - propagacja w dół (a), propagacja w górę (b) - w opcji bez ograniczenia obszaru rejestracji dla modelu 3
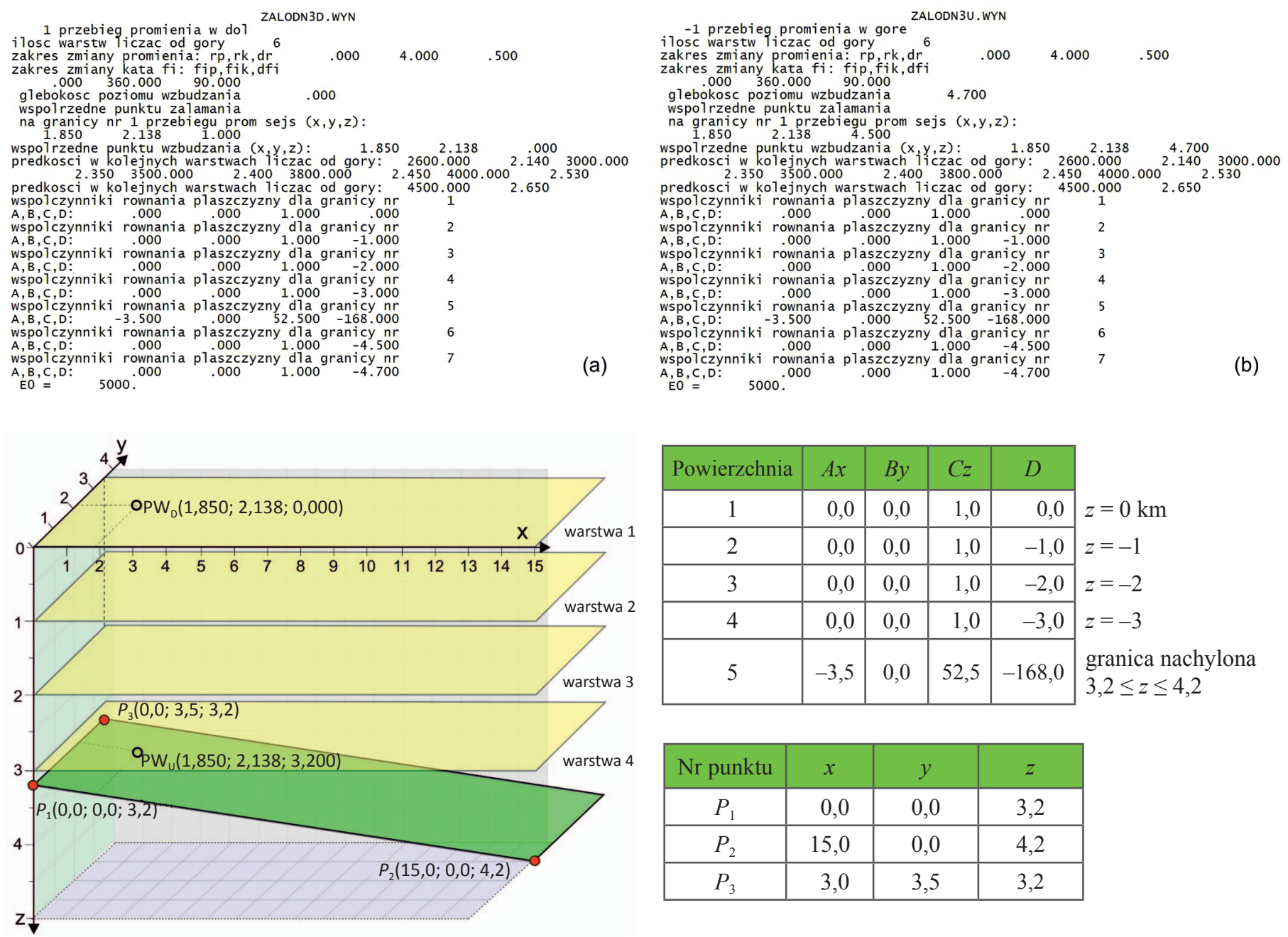

\begin{tabular}{|c|c|c|c|c|c|}
\hline Powierzchnia & $A x$ & By & $C z$ & $D$ & \\
\hline 1 & 0,0 & 0,0 & 1,0 & 0,0 & $z=0 \mathrm{~km}$ \\
\hline 2 & 0,0 & 0,0 & 1,0 & $-1,0$ & $z=-1$ \\
\hline 3 & 0,0 & 0,0 & 1,0 & $-2,0$ & $z=-2$ \\
\hline 4 & 0,0 & 0,0 & 1,0 & $-3,0$ & $z=-3$ \\
\hline 5 & $-3,5$ & 0,0 & 52,5 & $-168,0$ & $\begin{array}{l}\text { granica nachylona } \\
3,2 \leq z \leq 4,2\end{array}$ \\
\hline
\end{tabular}

Rys. 11. Geometria modelu 4 z nachyloną warstwą szczelinowaną (liczba warstw: 4; liczba powierzchni rozgraniczających: 5)

Powierzchnia trzecia jest nachylona i określona przez trzy punkty $P_{1}, P_{2}, P_{3}$ o współrzędnych $P_{1}(0 ; 0 ; 2), P_{2}(13 ; 0 ; 1,7)$, $P_{3}(0 ; 3,5 ; 2)$, analogicznie do modelu 1 (rysunek 8$)$.

Podobnie rysunki 10 i 11 .
Kolejnym obiektem testowania jest model 3, który został opisany następującymi parametrami (rysunek 10, tablica 2 a, b i tablica $3 \mathrm{a}, \mathrm{b})$ :

Przedstawione modele 1, 2 i 3 charakteryzowały się 
Tablica 4. Tabela deklaracji parametrów dla programu MIKROMOD 3D - propagacja w dół (a), propagacja w górę (b) - w opcji bez ograniczenia obszaru rejestracji

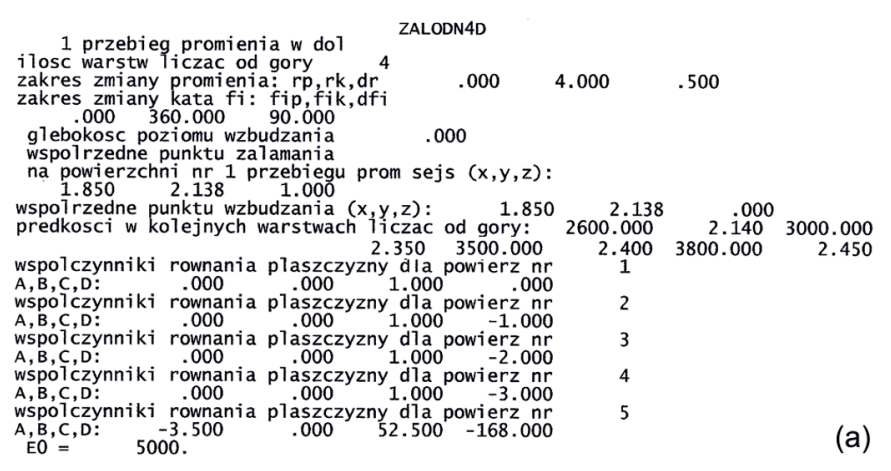

założeniem, że warstwa szczelinowana, na której w konsekwencji rozmieszczone są punkty wzbudzenia, jest równoległa do powierzchni ziemi. Natomiast w przypadku modelu 4 zaprojektowano warstwę szczelinowaną jako warstwę nachyloną (rysunek 11).

W modelu 4 zaprojektowany schemat akwizycji i punkty wzbudzenia ulokowane są na powierzchni nachylonej. Parametry wejściowe modelu 4 przedstawiono w tablicy $4 \mathrm{a}, \mathrm{b}$.

Testowanie programu modelowania mikrosejsmicznego jest istotnie różne od testowania programów dla modelowania

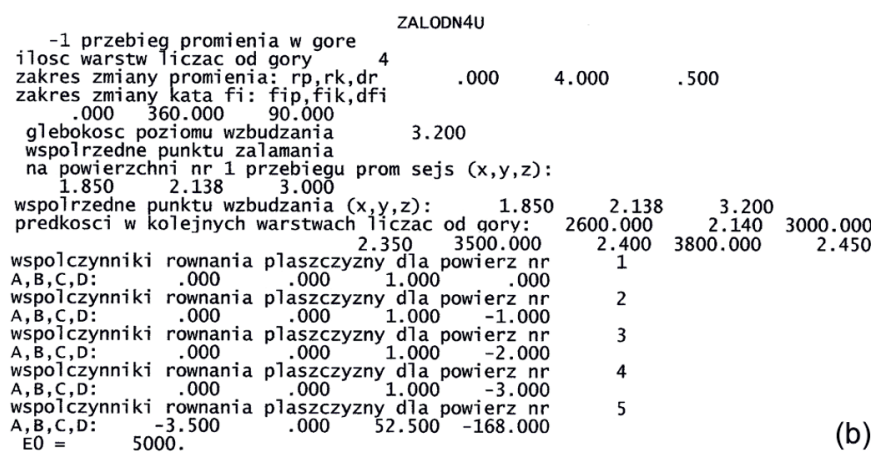

sejsmicznego, chociażby ze względu na efekt skali, który wynika z przedziału i zakresu wielkości analizowanych obiektów, jak też zmienności parametrów ośrodka - a zatem decyduje o relacjach dynamicznych obliczanego (ale też obserwowanego w praktyce) pola mikrosejsmicznego.

Uzyskane wyniki będą relacjonowane w kolejnej publikacji, zatytułowanej Modelowanie mikrosejsmiczne narzedziem wspomagania rozpoznawania i interpretacji geologicznej ośrodka oraz monitorowania efektów szczelinowania hydraulicznego.

\section{Uwagi końcowe}

Najczęściej spotykanym w literaturze dotyczącej mikrosejsmiki zdaniem jest stwierdzenie, że monitorowanie mikrosejsmiczne jest niezwykle wartościowym narzędziem śledzenia (tracking) skutków szczelinowania hydraulicznego, między innymi dzięki poprawie rozumienia procesów fizycznych odpowiadających za występowanie tzw. sejsmiczności wtórnej (induced seismicity).

Jak starano się pokazać, konieczna jest więc znajomość parametrów geomechanicznych ośrodka, rodzaju źródeł drgań sprężystych, zarówno naturalnych (np. tektoniczne), jak i generowanych przez człowieka (np. eksplozje), oraz mechanizmu źródła (opisanego przez tensor momentu sejsmicznego). Widzimy, że różnorodność i rozpiętość informacji jest bardzo duża, zatem poprawne zaprojektowanie sposobu monitorowania i schematu akwizycji oraz ocena i interpretacja wyników wymaga integracji wielu dziedzin - zarówno w domenie teorii, jak i praktyki. Pomimo że sejsmologia i metoda sejsmiczna są doskonale osadzone w rodzimej rzeczywistości, a ostatnio i geomechanika zaczyna występować jako standardowa aplikacja w przemyśle naftowym i górniczym, kompleksowo rozumiana mikrosejsmika znajduje się w Polsce w stadium początkowym.

Mikrosejsmika w zastosowaniu do monitorowania szczelinowania hydraulicznego, aby spełnić swoje zadanie, musi odpowiedzieć na znacznie trudniejsze pytania niż metoda sejsmiczna.
Jednym z najważniejszych jest pytanie o udział zarejestrowanej mikrosejsmiczności w całkowitej deformacji układu szczelin (total fracture network deformation). Konieczne wydaje się uwzględnienie elementów, które w literaturze anglojęzycznej noszą nazwę dry (suchych) - wywołanych przyczynami innymi niż szczelinowanie hydrauliczne, w odróżnieniu od przyczyn typu wet (mokrych), związanych ze szczelinowaniem.

Wymienione elementy, rozważane w konkretnym ośrodku geologicznym, generują kolejne pytania związane z budową i strukturą ośrodka, m.in.: upadem i rozciągłością warstw, rozkładem naturalnego pola naprężeń i relacją z rozkładem lokalnego pola naprężeń (local principal component).

W zaproponowanym w publikacji rozwiązaniu przyjęto, że w przypadku dość słabo rozpoznanego ośrodka i niejednoznacznego zapisu mikrosejsmicznego ważnym krokiem na drodze oceny efektów szczelinowania powinno być modelowanie pola mikrosejsmicznego. Mając na uwadze skomplikowaną budowę geologiczną obszarów występowania formacji łupkowych (zarówno o charakterze skały macierzystej, jak i kolektorskiej) w Polsce, przedstawiono algorytm i program, który umożliwia różne warianty obliczeń w zależności od specyfiki badanych obiektów, co potwierdzono licznymi testami na modelach.

Zaprezentowane celowo w sposób ogólny rozwiązanie algorytmiczno-programowe stanowić będzie przedmiot postępowania patentowego. 
Prosimy cytować jako: Nafta-Gaz 2016, nr 7, s. 487-501, DOI: 10.18668/NG.2016.07.01

Artykuł nadesłano do Redakcji 13.01.2016 r. Zatwierdzono do druku 6.04.2016 r.

Artykuł powstał na podstawie projektu badawczego pt. Wybór optymalnej technologii monitoringu mikrosejsmicznego w procesach szczelinowania hydraulicznego. Optymalizacja przetwarzania i interpretacji danych pomiarowych (GASLUPMIKROS) - obszar 2B. Zad. 2. Przetwarzanie i interpretacja danych mikrosejsmicznych oraz symulacje numeryczne fal generowanych $w$ procesie szczelinowania hydraulicznego, w tym mikrosejsmika - aktywna i pasywna - w celu określenia dynamicznych zmian w ośrodku wywołanych procesami udostepniania i eksploatacji formacji łupkowych - praca INiG - PIB na zlecenie NCBR; nr zlecenia 6113/SG, nr archiwalny: DK-4100-0601/10/13.

\section{Literatura}

[1] Baig A., Viegas G., Gallagher J., Urbancic T., von Lunen E. Constraining geomechanical models by using microseismicderived fractures from source mechanisms. The Leading Edge 2015, vol. 34, no. 8, s. 912-916.

[2] Baig A., Viegas G., Urbancic T., von Lunen E., Hendrick J.: To frac or not to frac: assessing potential damage as related to hydraulic fracture induced seismicity. First Break 2015, vol. 33, no. 7, s. 67-71.

[3] Barton N.: Non-linear behaviour for naturally fractured carbonates and frac-stimulated gas-shales. First Break 2014, vol. 32 , no. 9, s. 51-66.

[4] Barton N.: Rock Quality, Seismic Velocity, Attenuation and Anisotropy. Taylor \& Francis Group - London, Leiden, New York, Philadelphia, Singapore, 2007.

[5] Del Monte A. A.: Seismic petrophysics: Part 1. The Leading Edge 2015, vol. 34, no. 4, s. 440-442.

[6] Del Monte A. A.: Seismic petrophysics: Part 2. The Leading Edge 2015, vol. 34, no. 6, s. 700-704.

[7] Diller D. E., Shuck T., Fish B.: Estimation and interpretation of high-confidence microseismic source mechanisms. The Leading Edge 2015, vol. 34, no. 8, s. 918-924.

[8] Eaton D. W., Maghsoudi S.: $2 b$... or not 2b? Interpreting magnitude distributions from microseismic catalogs. First Break 2015, vol. 33, no. 10, s. 79-86.

[9] Eisner L.: Microseismic monitoring in oil or gas reservoirs. Outline of the Course. Czeska Republika, Praha, 7-8 October 2013.

[10] Eyre T. S., van der Baan M.: Overview of moment-tensor inversion of microseismic events. The Leading Edge 2015, vol. 34 , no. 8 , s. 882-888.

[11] Goodway B.: Introduction to this special section: Passive seismic and microseismic - Part 1. The Leading Edge 2012, vol. 31, no. 11, s. 1296-1299.

[12] Herwanger J., Koutsabeloulis N.: Seismic Geomechanics: How to Build and Calibrate Geomechanical Models using 3D and 4D Seismic Data. EAGE, 2011.

[13] Jaeger J. C., Cook N. G. W., Zimmerman R. W.: Fundamentals of Rock Mechanics. Malden, Oxford, Carlton, Blackwell Publishing, 2007.

[14] Jędrzejowska-Tyczkowska H.: Algorithm for computing kinematic and dynamic characteristics of the total field of head waves in a plane - parallel multilayer medium. Acta Geophysica Polonica 1974, vol. 22, no. 1, s. 43-63.

[15] Jędrzejowska-Tyczkowska H.: Niejawne aspekty procedur zwiększenia rozdzielczości i rozszerzenia zakresu częstotliwości sejsmicznego pola falowego. [W:] Rzeczpospolita tupkowa - Studium wiedzy o gazie tupkowym. Prace Naukowe INiG 2012, nr 183, s. 71-89.

[16] Jędrzejowska-Tyczkowska H.: Perspektywy i potrzeby w świetle wyzwań, jakie polskim naukowcom i inżynierom niesie odkrywanie i eksploatacja gazu z formacji łupkowych. [W:] Rzeczpospolita tupkowa - Studium wiedzy o gazie tupkowym. Prace Naukowe INiG 2012, nr 183, s. 43-70.

[17] Jędrzejowska-Tyczkowska H.: Polish Shale Gas. Nafta-Gaz 2011, nr 5, s. 307-309.

[18] Jędrzejowska-Tyczkowska H.: Renesans roli akwizycji w metodzie sejsmicznej $w$ świetle poszukiwań niekonwencjonalnych złóż węglowodorów. Nafta-Gaz 2011, nr 11, s. 777-792.

[19] Jędrzejowska-Tyczkowska H.: Sejsmika 4D - najefektywniejsze narzedzie monitorowania $i$ weryfikacji $w$ zadaniach sekwestracji $\mathrm{CO}_{2}$. Prace Naukowe INiG 2010, nr 166.

[20] Jędrzejowska-Tyczkowska H.: Sejsmika refleksyjna i mikrosejsmika - podstawowe narzędzie poszukiwań i monitorowania węglowodorów w złożach niekonwencjonalnych. Wydawnictwo Akademii Górniczo-Hutniczej, 2011.

[21] Jędrzejowska-Tyczkowska H.: Some methods of development monitoring of oil and gas fields and CO2 storage with help of elastic seismic fields. Бурение \& Нефть, Март 2013, s. 18-23.

[22] Jędrzejowska-Tyczkowska H.: The Impact of Phase Characteristics on Seismic Data Resolution. Second EAGE/SBGf Workshop 2014, 4-5 November, Copacabana, Rio de Janeiro, Brazil.

[23] Jędrzejowska-Tyczkowska H.: The influence of disturbances and noise of normal distribution on the correctness of geological interpretation of seismic sections with increased resolution. Nafta-Gaz 2015, nr 12, s. 931-943.

[24] Jędrzejowska-Tyczkowska H., Davis T. L.: Wanted and unwanted effects of surface seismic data resolution improvements. First Break 2012, vol. 30, no. 9, s. 75-82.

[25] Jędrzejowska-Tyczkowska H., Słota-Valim M.: Mechaniczny Model Ziemi. Nowy i konieczny warunek sukcesu w poszukiwaniach i eksploatacji złóż niekonwencjonalnych. [W:] Rzeczpospolita tupkowa - Studium wiedzy o gazie tupkowym. Prace Naukowe INiG 2012, nr 183, s. 15-26.

[26] Jędrzejowska-Tyczkowska H., Sowiżdżał K.: Importance of seismic data resolution on geological results of multidisciplinary geophysical research including $3 D$ geological modelling. International Conference „Engineering and Telecommunications Technology”, Moscow, 26-28 November 2014. Publisher IEEE Computer Society, Los Alamitos, CA, USA, s. 116-117.

[27] Jędrzejowska-Tyczkowska H., Ziemianin K.: Zagadnienie skali w zintegrowanym. dynamicznym procesie poszukiwań, opisu oraz eksploatacji niekonwencjonalnych złóż węglowodorów. [W:] Rzeczpospolita tupkowa-Studium wiedzy o gazie tupkowym. Prace Naukowe INiG 2012, nr 183, s. 27-42.

[28] Jędrzejowska-Tyczkowska H., Żukowska K., Irlik I.: Rola modelowania mikrosejsmicznego w procesie monitorowania szczelinowania hydraulicznego. Prace Naukowe INiG, Geopetrol 2014. 
[29] Jędrzejowska-Tyczkowska H., Żukowska K., Malaga M.: Możliwości sejsmiki ,time-lapse” (4D) w zadaniach obliczania ciśnienia górotworu i ciśnień porowych. Actual Problems of Geosciences, Moscow, October 2008, Schmidt Institute of Physics of the Earth RAS (IPE RAS).

[30] Kamei R., Nakata N., Lumley D.: Introduction to microseismic source mechanisms. The Leading Edge 2015, vol. 34, no. 8, s. $876-878$

[31] Kowalski H., Godlewski P., Kobusiński W., Makarewicz W., Podolak M., Nowicka A., Mikołajewski Z., Chase D., Dafni R., Canning A., Koren Z.: Imaging and characterization of a shale reservoir onshore Poland, using full-azimuth seismic depth imaging. First Break 2014, vol. 32, no. 10, s. 101-109.

[32] Labuz J. F., Zang A.: Mohr-Coulomb failure criterion. Rock Mech. Rock Eng. 2012, vol. 45, no. 6, s. 975-979.

[33] Maxwell S. C., Chorney D., Goodfellow S. D.: Microseismic geomechanics of hydraulic-fracture networks: Insights into mechanisms of microseismic sources. The Leading Edge 2015, vol. 34, no. 8, s. 904-906.

[34] Maxwell S. C., Zhang F., Damjanac B.: Geomechanical modeling of induced seismicity resulting from hydraulic fracturing. The Leading Edge 2015, vol. 34, no. 6, s. 678-683.

[35] Meija C., Arbelaez I., Acosta E., et al.: An integrated workflow for hydraulic fracture stage design. First Break 2015, vol. 33, no. 10, s. 51-57.

[36] Rodriguez-Pradilla G.: Microseismic monitoring of a hydraulic-fracturing operation in a CBM reservoir: Case study in the Cerrejón Formation, Cesar-Rancheria Basin, Colombia The Leading Edge 2015, vol. 34, no. 8, s. 896-902.

[37] Rutledge J., Yu X., Leaney S.: Microseismic shearing driven by hydraulic-fracture opening: An interpretation of sourcemechanism trends. The Leading Edge 2015, vol. 34, no. 8, s. 926-934.

[38] Shemeta J., Goodway B., Willis M., Heigl W.: An introduction to this special section: Passive seismic and microseismic Part 2. The Leading Edge 2012, vol. 31, no. 12, s. 1428-1435.

[39] Shuck T., Diller D. E., Fish B., Smith P., Wallace K.: Surface microseismic in an extreme environment. The Leading Edge 2015, vol. 34, no. 8, s. 936-943.

[40] Staněk F., Jechumtálová Z., Eisner L.: Reservoir stress from microseismic source mechanisms. The Leading Edge 2015, vol. 34 , no. 8 , s. 890-895.

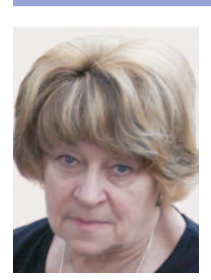

Prof. nzw. dr hab. inż. Halina JĘDRZEJOWSKA-TYCZKOWSKA

Instytut Nafty i Gazu - Państwowy Instytut Badawczy ul. Lubicz $25 \mathrm{~A}$

31-503 Kraków

E-mail:tyczkowska@inig.pl

\section{OFERTA}

\section{ZAKŁAD GEOLOGII I GEOCHEMII}

Zakres działania:

- analiza systemów naftowych (badania skał macierzystych, modelowanie generacji, ekspulsji i migracji węglowodorów, analiza dróg migracji, analiza parametrów zbiornikowych pułapek złożowych);

- badaniaprospekcyjne(trendy przestrzennegorozwojuparametrówzbiornikowych i filtracyjnych, analiza macierzystości, ranking stref zbiornikowych);

- konstrukcja statycznych modeli geologiczno-złożowych 3D;

- $\quad$ analiza procesów diagenetycznych i ich wpływu na parametry zbiornikowe skał;

- genetyczna korelacja płynów złożowych ze skałami macierzystymi;

- obliczanie zasobów złóż węglowodorów z analizą niepewności;

- $\quad$ modele przepływu płynów złożowych w skałach zbiornikowych;

- badania ekshalacji gazu;

- badania złóż typu tight/shale gas;

- $\quad$ specjalistyczne analizy: przestrzeni porowej, petrograficzne, geochemiczne RSO, płynów złożowych, analizy: biomarkerów, chromatograficzne, GC/MS, GC/MS/MS, składu izotopowego GC-IRMS

- interpretacja danych geofizyki wiertniczej.

Kierownik: dr inż. Grzegorz Leśniak

Adres: ul. Lubicz 25 A, 31-503 Kraków

Telefon: 126177687

Faks: 124303885

E-mail: grzegorz.lesniak@inig.pl

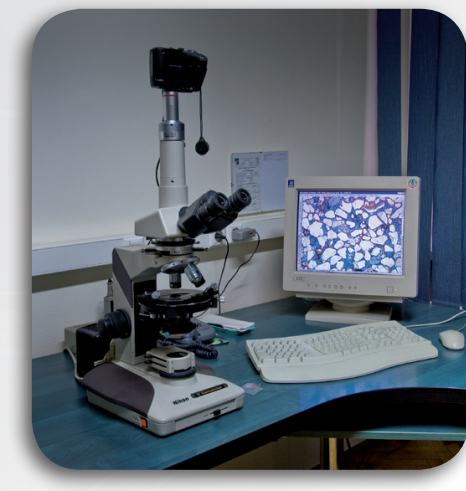

